\title{
Site-Selective Aerobic C-H Monoacylation of Carbazoles Using Palladium Catalysis
}

\author{
Subhadip Maiti, ${ }^{\neq}$Tirtha Mandal, ${ }^{\neq}$Barada Prasanna Dash ${ }^{\$}$ and Jyotirmayee Dash* ${ }^{* \neq}$ \\ ${ }^{*}$ School of Chemical Sciences, Indian Association for the Cultivation of Science, Jadavpur, \\ Kolkata 700032, India, correspondence email: ocjd@iacs.res.in \\ ${ }^{\$}$ Department of Chemistry, Siksha 'O' Anusandhan (Deemed to be University), Bhubaneswar, \\ Odisha, 751 030, India
}

\section{Contents}

1.0 Synthesis of pyridine protected carbazole derivatives

2.0 Reaction optimization

3.0 Labelling experiment

4.0 Radical quenching experiment

5.0 X-Ray crystallography data 
1.0 Synthesis of pyridine protected carbazole derivatives.

1.0.1 General procedure for the synthesis of carbazole derivatives 1,5 and 8 .<smiles>[X]c1ccc2[nH]c3ccc([X])cc3c2c1</smiles>

S1: $X_{1}=H, X_{2}=H$

s2: $\mathrm{X}_{1}=\mathrm{Cl}, \mathrm{X}_{2}=\mathrm{Cl}$

S3: $\mathrm{X}_{1}=\mathrm{H}, \mathrm{X}_{2}=\mathrm{Cl}$

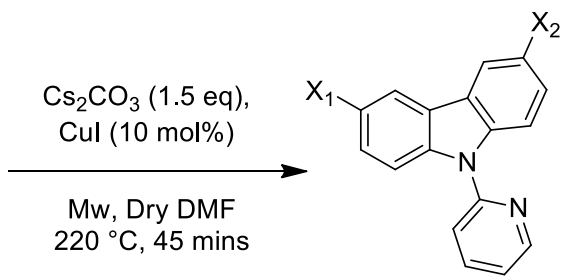

$$
\begin{aligned}
& \text { 1: } X_{1}=H, X_{2}=H \\
& \text { 5: } X_{1}=C l, X_{2}=C l \\
& \text { 8: } X_{1}=H, X_{2}=C l
\end{aligned}
$$

Scheme S1. Synthesis of pyridine protected carbazole derivatives $\mathbf{1}, \mathbf{5}, \mathbf{8}$.

1.0.2 General procedure for the synthesis of 3,6-dibromo-9-(pyridin-2-yl)-9H-carbazole 6.<smiles>c1ccc(-n2c3ccccc3c3ccccc32)nc1</smiles>

1

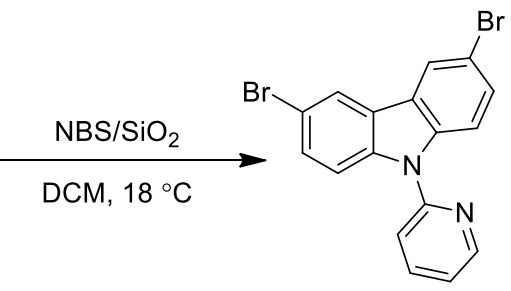

Scheme S2. Synthesis of pyridine protected 3,6-dibromo carbazole 6.

1.0.3 General procedure for the synthesis of 3,6-diiodo-9-(pyridin-2-yl)-9H-carbazole 7.<smiles>c1ccc(-n2c3ccccc3c3ccccc32)nc1</smiles>

1

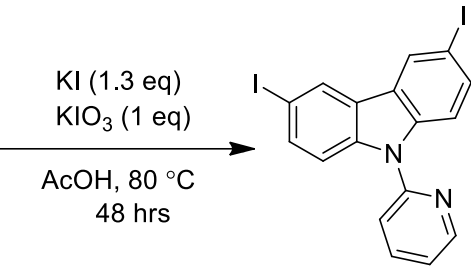

7

Scheme S3. Synthesis of pyridine protected 3,6-diiodo carbazole 7.

\subsection{Reaction optimization:}

Table S1. Catalyst and co-catalyst loading (mol \%) screening

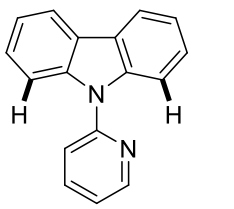

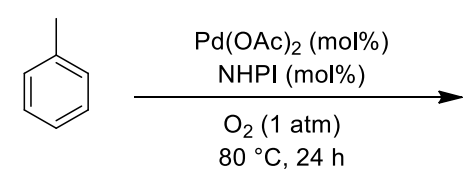

$2 a$

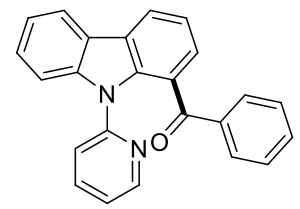

$3 a$

\begin{tabular}{cccc}
\hline Entry & $\operatorname{Pd}(\mathrm{OAc})_{2}(\mathrm{~mol} \%)$ & NHPI $(\mathrm{mol} \%)$ & Yield of 3a $(\%)^{\mathrm{a}}$ \\
\hline 1 & 2 & 10 & Trace
\end{tabular}




$\begin{array}{lccc}2 & 2 & 30 & 10 \\ 3 & 5 & 30 & 40 \\ 4 & 10 & 30 & 76 \\ 5 & 10 & 10 & 30 \\ 6 & 10 & 20 & 50\end{array}$

${ }^{\mathrm{a}}$ Isolated yields after column chromatography

\subsection{Labelling experiment:}

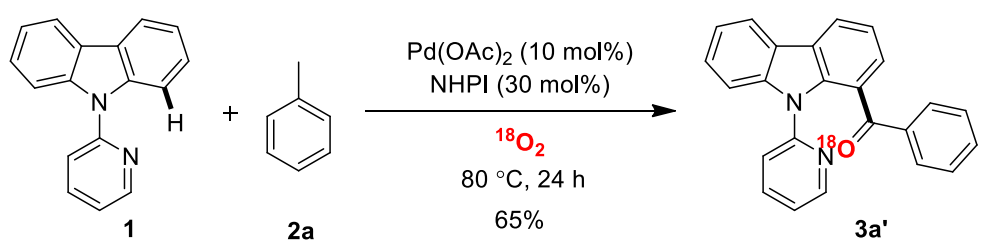

Scheme S4. ${ }^{18} \mathrm{O}$ labelling experiment.

\section{HRMS data:}

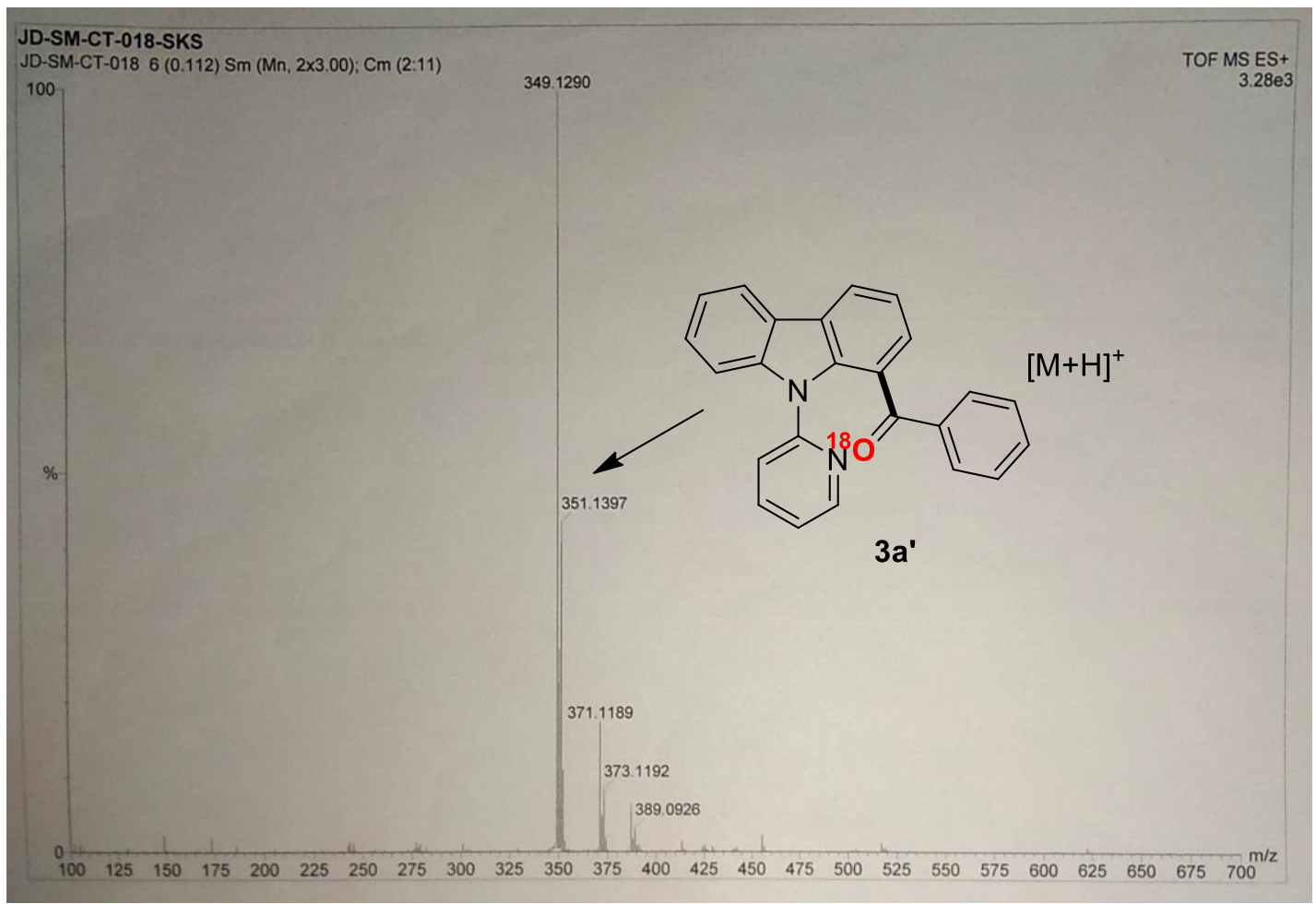

\subsection{Radical quenching experiment:}

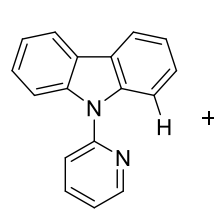

1

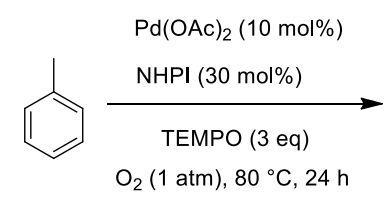

$2 a$

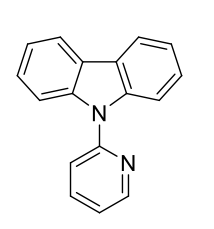

$1(0 \%)$

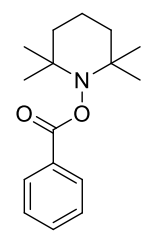

$19(70 \%)$

Scheme S5. Reaction in presence of a radical scavenger. 
${ }^{1} \mathrm{H}$ and ${ }^{13} \mathrm{C}$ NMR of compound 19:
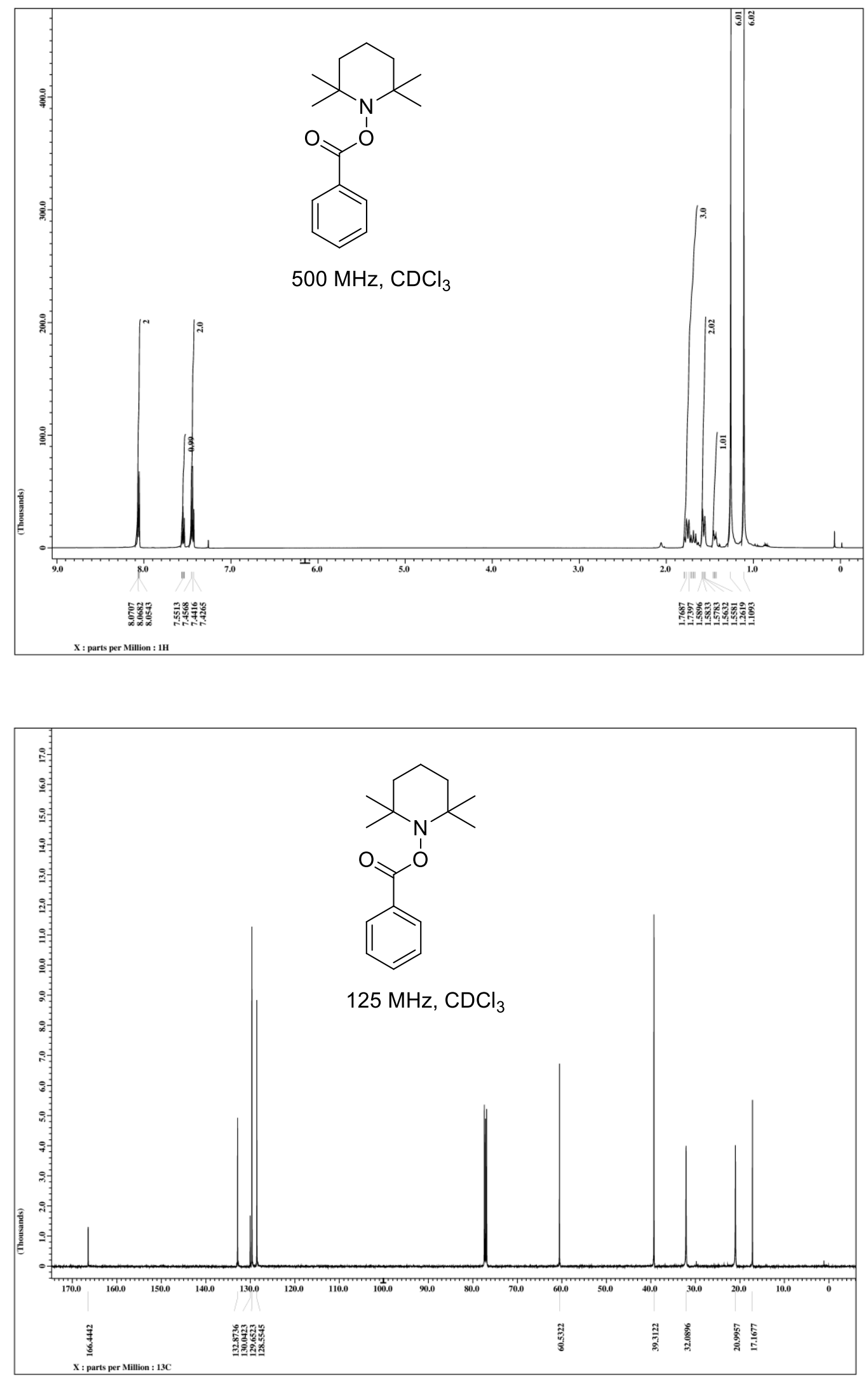
5.0 X-Ray Crystallography of compounds 3f, 3i and 13a: Intensity data were collected on a Bruker's Kappa Apex II CCD Duo diffractometer with graphite monochromated MoK $\alpha$ radiation $(0.71073 \AA)$ at the temperature of $296 \mathrm{~K}$. Scaling and multi-scan absorption correction were employed using SADABS. The structure was solved by direct methods and all the non-hydrogen atoms were refined anisotropically while the hydrogen atoms fixed in the predetermined positions by Shelxs-97 and Shelxl-97 packages respectively.

\section{Crystal data and structure refinement for 3f.}

Empirical formula

$\mathrm{C}_{24} \mathrm{H}_{15} \mathrm{FN}_{2} \mathrm{O}$

Formula weight

366.38

Temperature/K

293.15

Crystal system

Monoclinic

Space group

$\mathrm{P} 21$

$\mathrm{a} / \AA$

9.245(3)

$\mathrm{b} / \AA$

11.115(4)

$\mathrm{c} / \AA$

9.401(3)

$\alpha /{ }^{\circ}$

90

$\beta /{ }^{\circ}$

$112.358(5)$

$\gamma /{ }^{\circ}$

90

Volume/ $\AA^{3}$

893.4(5)

$\mathrm{Z}$

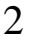

$\rho_{\text {calc }} \mathrm{g} / \mathrm{cm}^{3}$

1.362

$\mu / \mathrm{mm}^{-1}$

0.091

$\mathrm{F}(000)$

380.0

Radiation

$\operatorname{MoK} \alpha(\lambda=0.71073)$

$2 \Theta$ range for data collection $/{ }^{\circ} 4.684$ to 49.998

Index ranges

$-10 \leq \mathrm{h} \leq 10,-13 \leq \mathrm{k} \leq 13,-11 \leq 1 \leq 10$

Reflections collected

5975

Independent reflections

$3037\left[\mathrm{R}_{\text {int }}=0.0332, \mathrm{R}_{\text {sigma }}=0.0560\right]$

Data/restraints/parameters

$3037 / 1 / 254$

Goodness-of-fit on $\mathrm{F}^{2}$

1.022

Final $R$ indexes $[\mathrm{I}>=2 \sigma(\mathrm{I})] \quad \mathrm{R}_{1}=0.0435, \mathrm{wR}_{2}=0.0848$

Final $\mathrm{R}$ indexes [all data] $\quad \mathrm{R}_{1}=0.0740, \mathrm{wR}_{2}=0.0979$

Largest diff. peak/hole / e $\AA^{-3} 0.13 /-0.12$ 


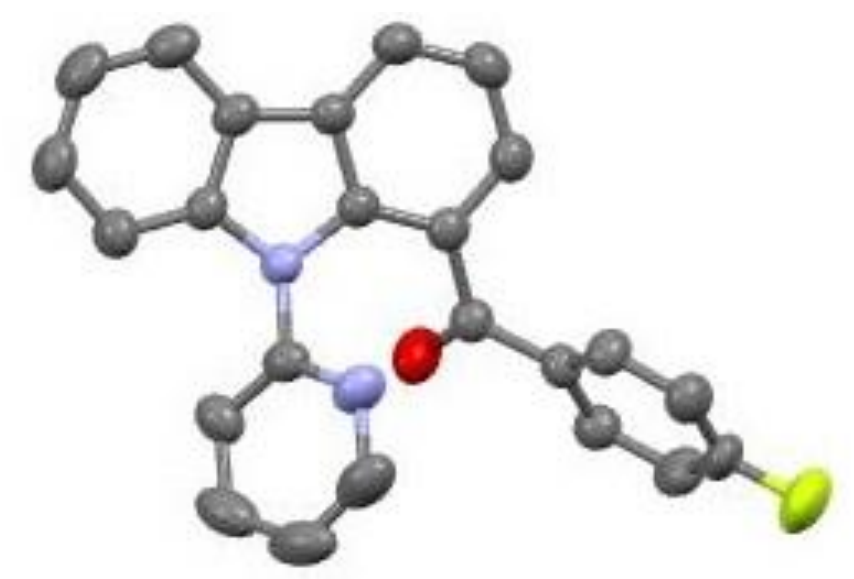

Figure S1.The ORTEP diagram of $\mathbf{3 f}$ showing $50 \%$ probability thermal ellipsoid.

\section{Crystal data and structure refinement for $3 \mathrm{i}$.}

Empirical formula

Formula weight

Temperature/K

Crystal system

Space group

$\mathrm{a} / \AA$

$\mathrm{b} / \AA$

$\mathrm{c} / \AA$

$\alpha /{ }^{\circ}$

$\beta /{ }^{\circ}$

$\gamma /{ }^{\circ}$

Volume $/ \AA^{3}$

$\mathrm{Z}$

$\rho_{\text {calc }} \mathrm{g} / \mathrm{cm}^{3}$

$\mu / \mathrm{mm}^{-1}$

$\mathrm{F}(000)$

Radiation
$\mathrm{C}_{25} \mathrm{H}_{15} \mathrm{~N}_{3} \mathrm{O}$

373.40

127.8

Monoclinic

$\mathrm{P} 21$

9.7002(7)

$10.7554(7)$

9.7556(7)

90

$116.701(2)$

90

$909.26(11)$

2

1.364

0.085

388.0

$\operatorname{MoK} \alpha(\lambda=0.71073)$

$2 \Theta$ range for data collection $/{ }^{\circ} 6.016$ to 49.996

Index ranges

$-11 \leq \mathrm{h} \leq 11,-12 \leq \mathrm{k} \leq 12,-11 \leq 1 \leq 11$

Reflections collected

8858

Independent reflections

$2888\left[\mathrm{R}_{\text {int }}=0.0307, \mathrm{R}_{\text {sigma }}=0.0323\right]$

Data/restraints/parameters

$2888 / 1 / 263$

Goodness-of-fit on $\mathrm{F}^{2}$

1.065

Final $R$ indexes $[\mathrm{I}>=2 \sigma(\mathrm{I})] \quad \mathrm{R}_{1}=0.0267, \mathrm{wR}_{2}=0.0611$

Final $\mathrm{R}$ indexes [all data] $\quad \mathrm{R}_{1}=0.0287, \mathrm{wR}_{2}=0.0628$

Largest diff. peak/hole / e $\AA^{-3} 0.15 /-0.12$ 


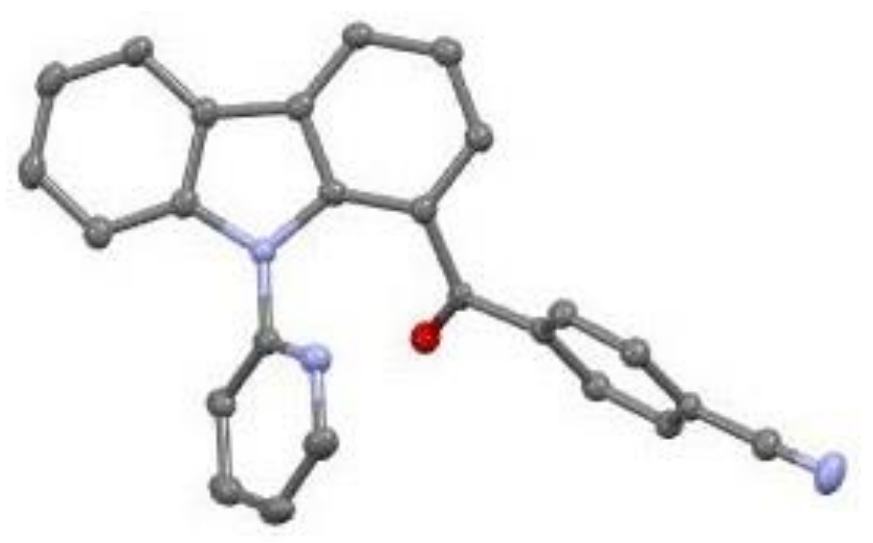

Figure S2.The ORTEP diagram of 3i showing 50\% probability thermal ellipsoid..

\section{Crystal data and structure refinement for $13 a$.}

Empirical formula

Formula weight

Temperature/K

Crystal system

Space group

$\mathrm{a} / \AA$

$\mathrm{b} / \AA$

$\mathrm{c} / \AA$

$\alpha /{ }^{\circ}$

$\beta /{ }^{\circ}$

$\gamma /{ }^{\circ}$

Volume $/ \AA^{3}$

Z

$\rho_{\text {calc }} \mathrm{g} / \mathrm{cm}^{3}$

$\mu / \mathrm{mm}^{-1}$

$\mathrm{F}(000)$

Radiation
$\mathrm{C}_{24} \mathrm{H}_{15} \mathrm{ClN}_{2} \mathrm{O}$

382.83

129.48

Monoclinic

$\mathrm{P} 21 / \mathrm{n}$

8.2726(4)

13.1774(5)

16.4996(6)

90

93.7720(10)

90

1794.75(13)

4

1.417

0.231

792.0

$\operatorname{MoK} \alpha(\lambda=0.71073)$

$2 \Theta$ range for data collection $/{ }^{\circ} 5.374$ to 52.766

Index ranges

Reflections collected

$-10 \leq \mathrm{h} \leq 10,-16 \leq \mathrm{k} \leq 16,-20 \leq 1 \leq 19$

17091

$3640\left[\mathrm{R}_{\text {int }}=0.0240, \mathrm{R}_{\text {sigma }}=0.0193\right]$

$3640 / 0 / 253$

1.043

Goodness-of-fit on $\mathrm{F}^{2}$

$\mathrm{R}_{1}=0.0321, \mathrm{wR}_{2}=0.0773$

$\mathrm{R}_{1}=0.0372, \mathrm{wR}_{2}=0.0810$

Final $\mathrm{R}$ indexes [all data] $\quad \mathrm{R}_{1}=0$.

Largest diff. peak/hole / e $\AA^{-3} 0.28 /-0.33$ 


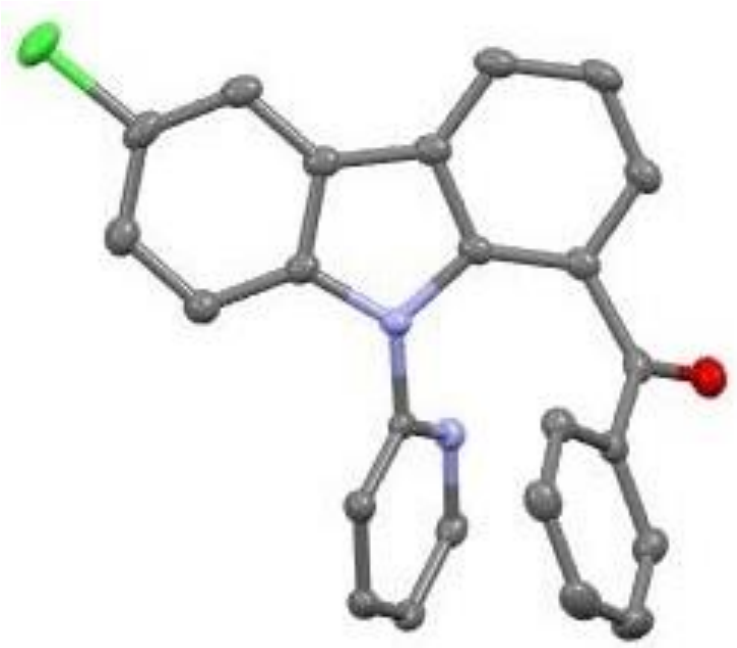

Figure S3.The ORTEP diagram of 13a showing 50\% probability thermal ellipsoid. 
6.0 NMR spectra of all compounds

${ }^{1} \mathrm{H}$ and ${ }^{13} \mathrm{C}$ NMR of compound 5 :
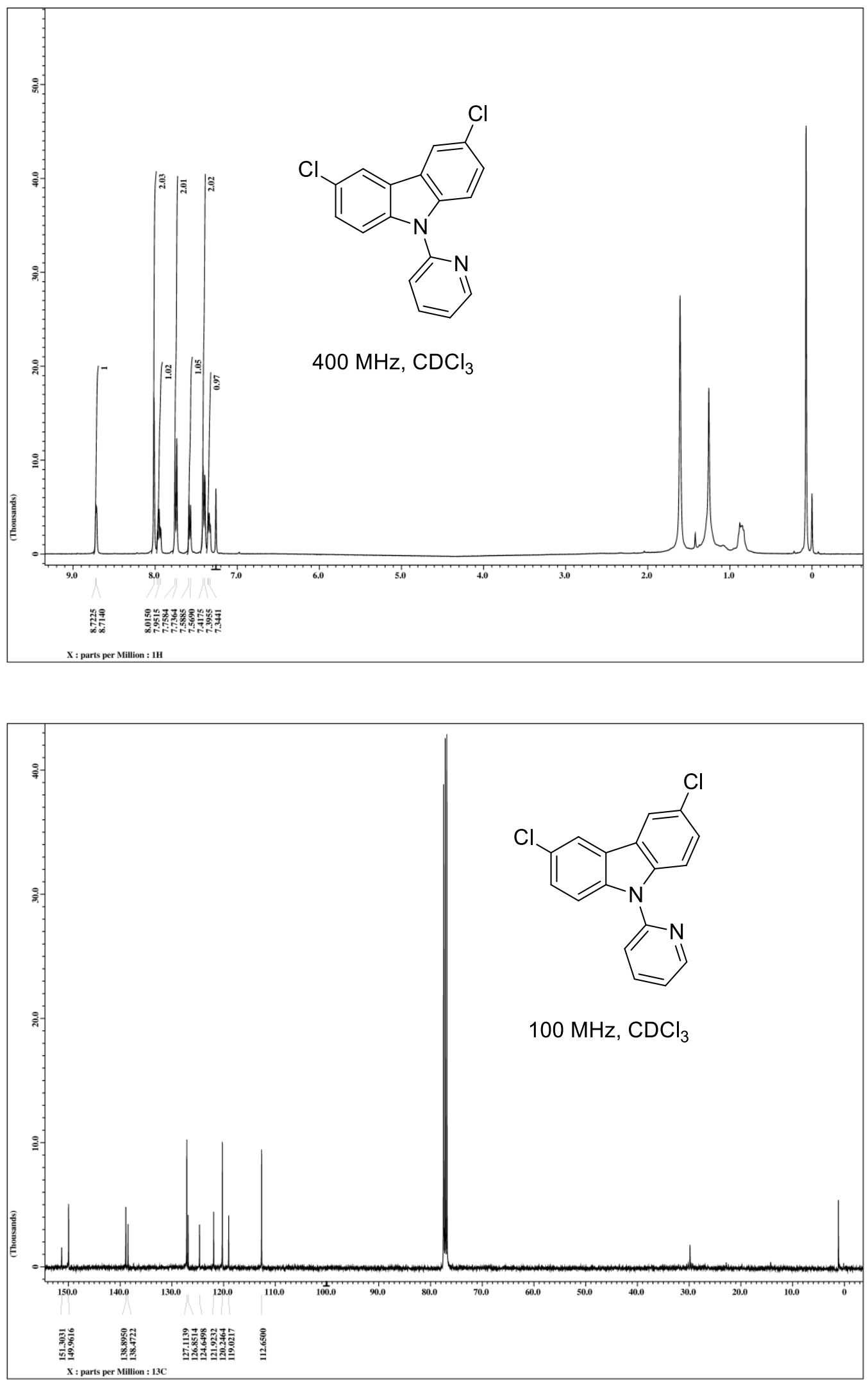
${ }^{1} \mathrm{H}$ and ${ }^{13} \mathrm{C}$ NMR of compound $\mathbf{8}$ :
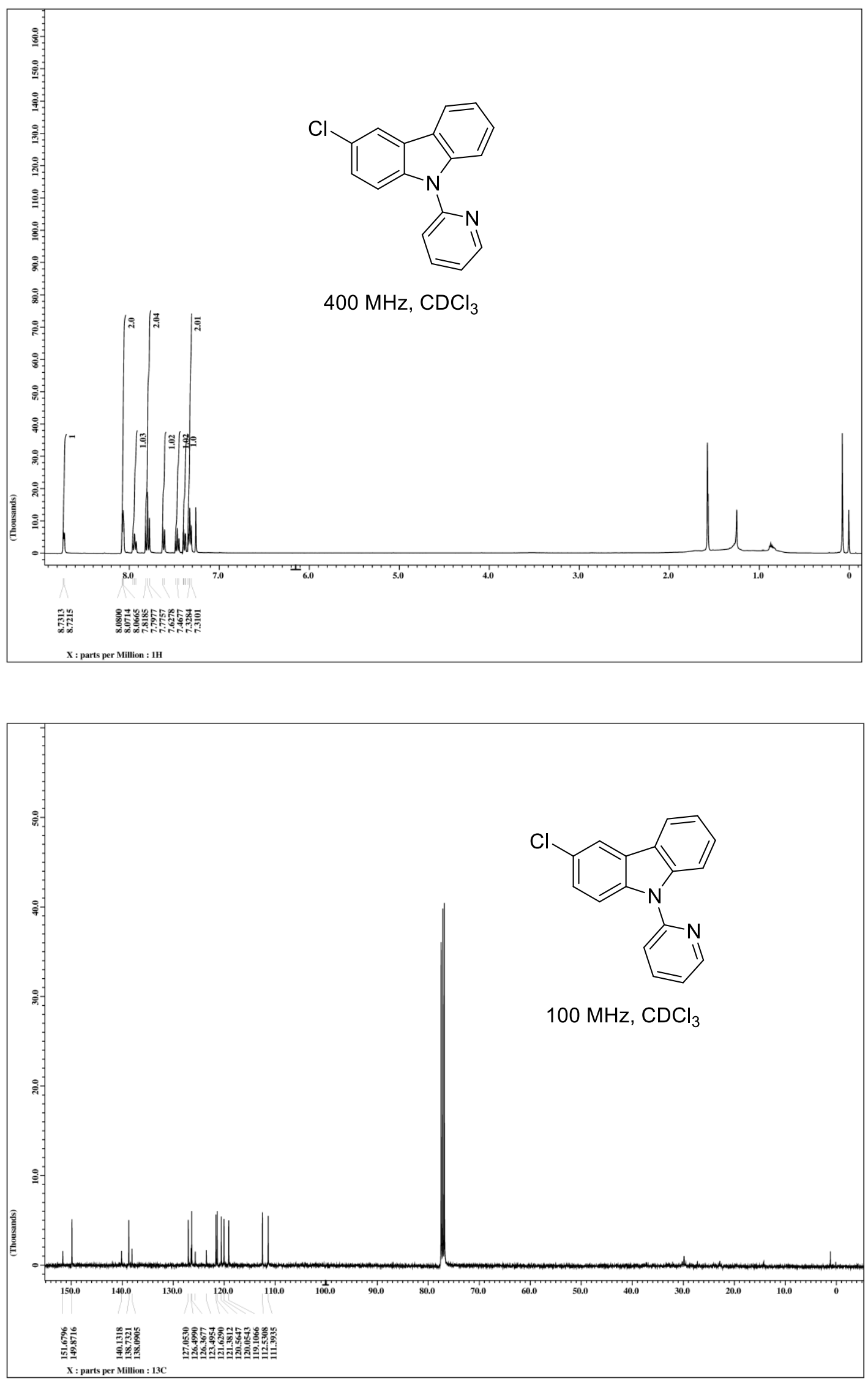
${ }^{1} \mathrm{H}$ and ${ }^{13} \mathrm{C}$ NMR of compound $\mathbf{6}$ :
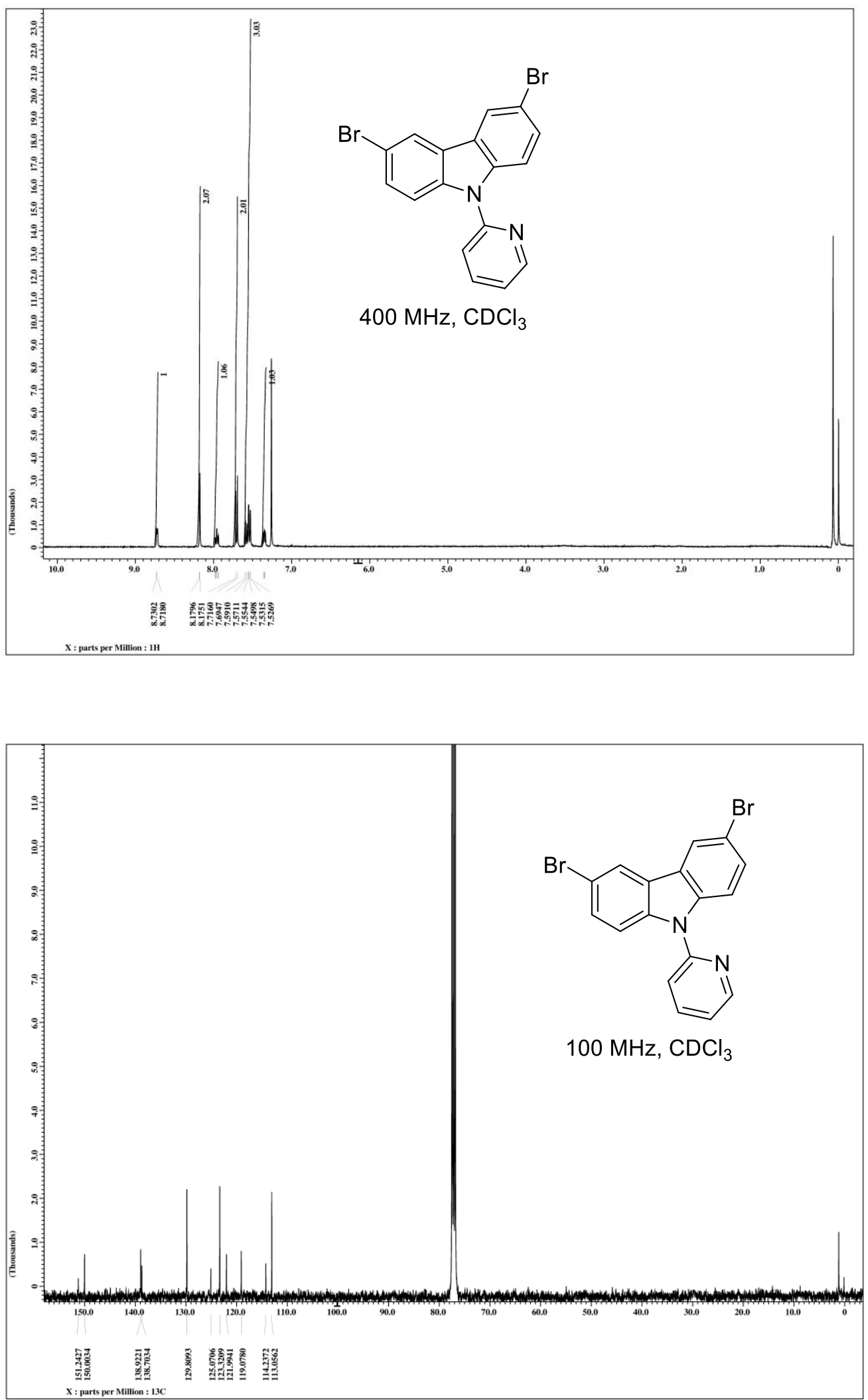
${ }^{1} \mathrm{H}$ and ${ }^{13} \mathrm{C}$ NMR of compound 7:
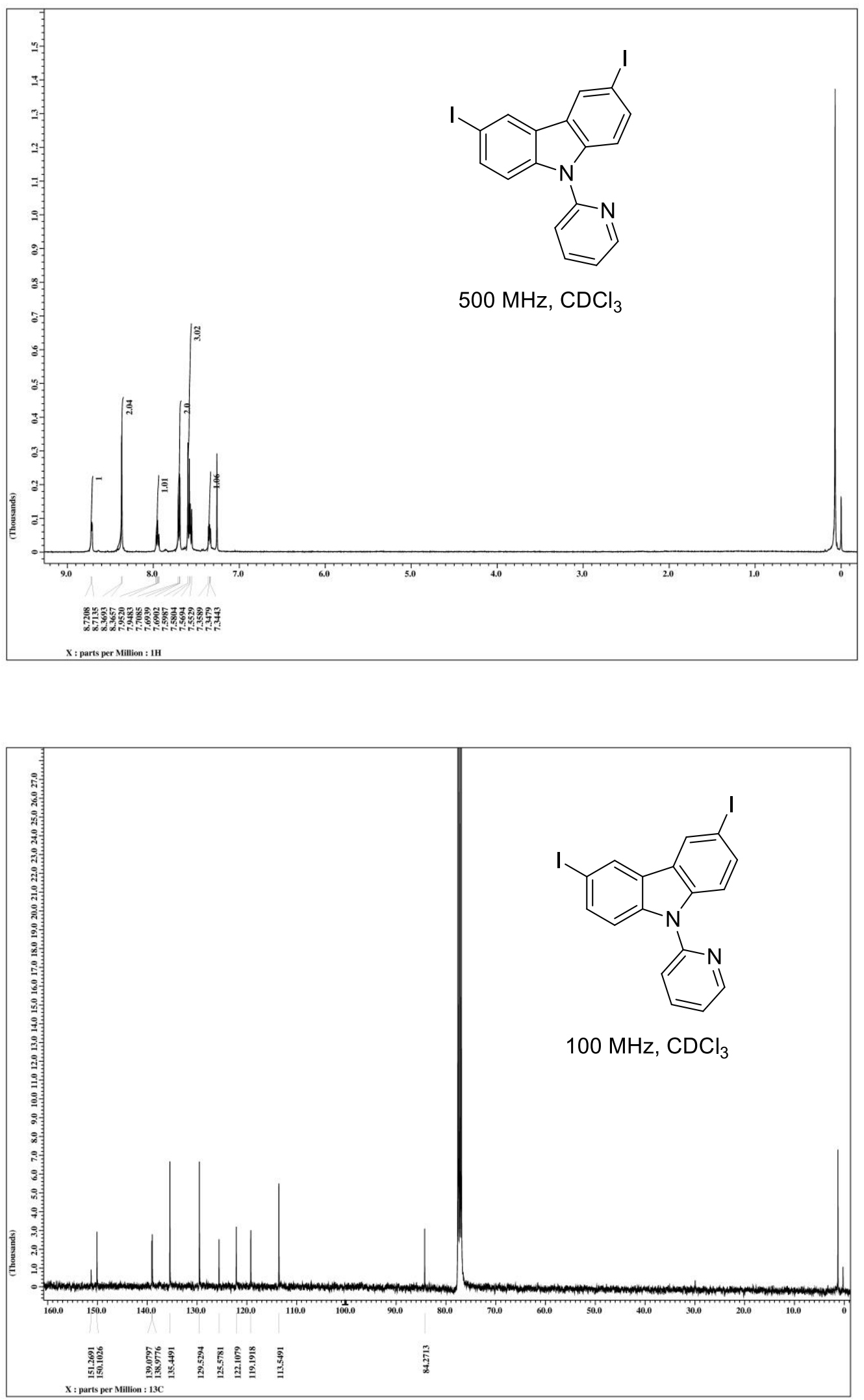
${ }^{1} \mathrm{H}$ and ${ }^{13} \mathrm{C}$ NMR of compound 3a:
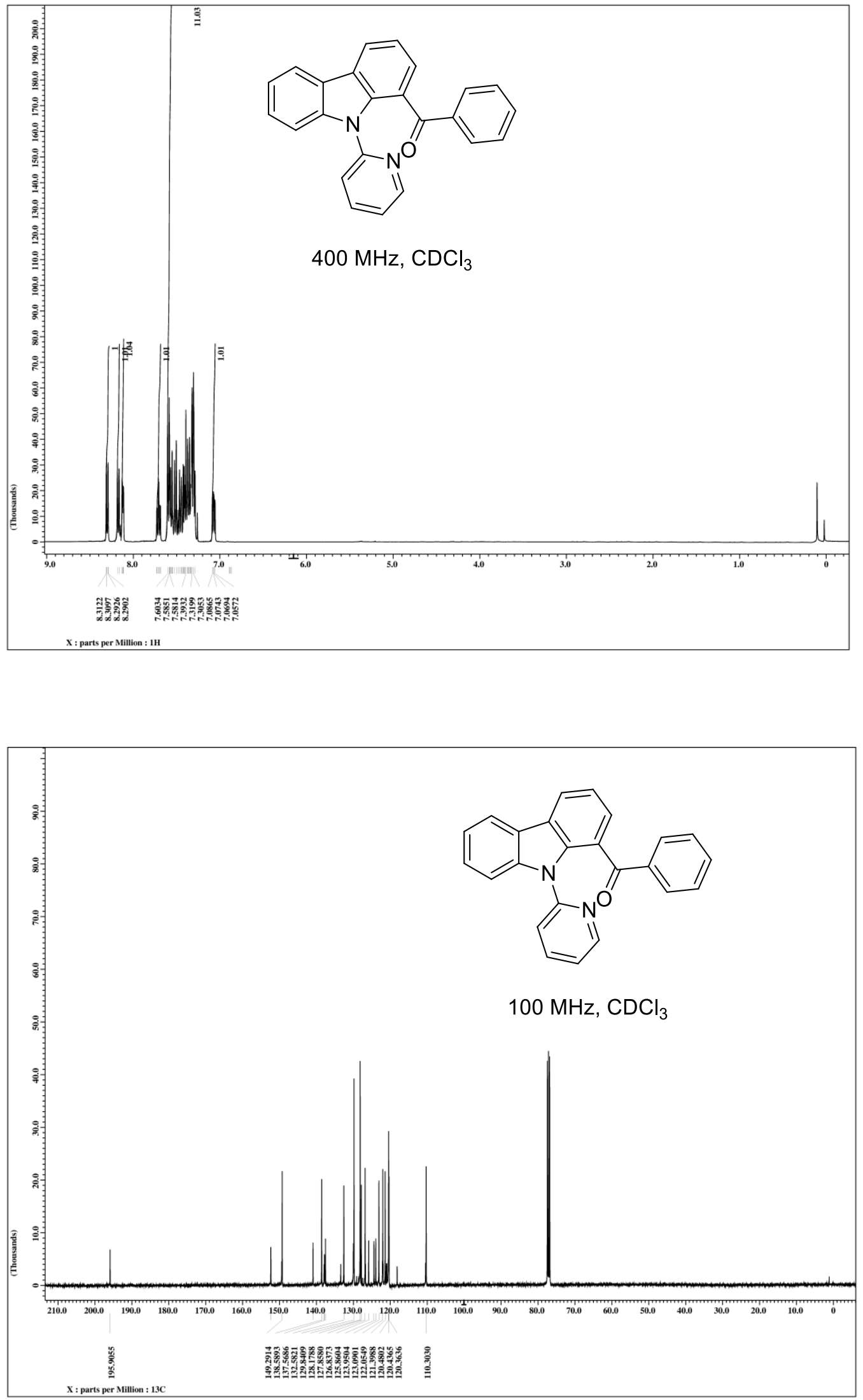
${ }^{1} \mathrm{H}$ and ${ }^{13} \mathrm{C}$ NMR of compound $\mathbf{3 b}$ :
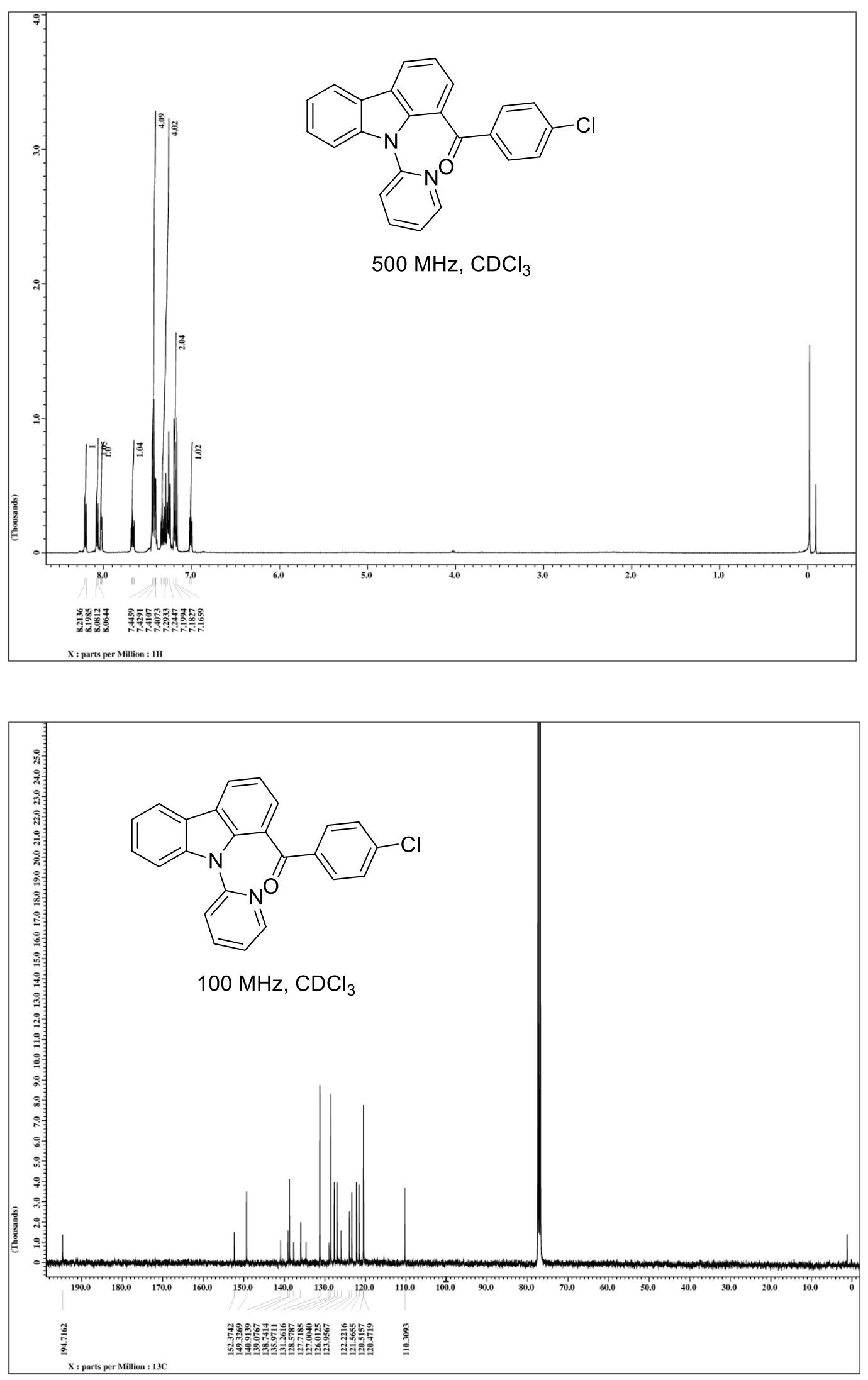
${ }^{1} \mathrm{H}$ and ${ }^{13} \mathrm{C}$ NMR of compound $3 \mathrm{c}$ :
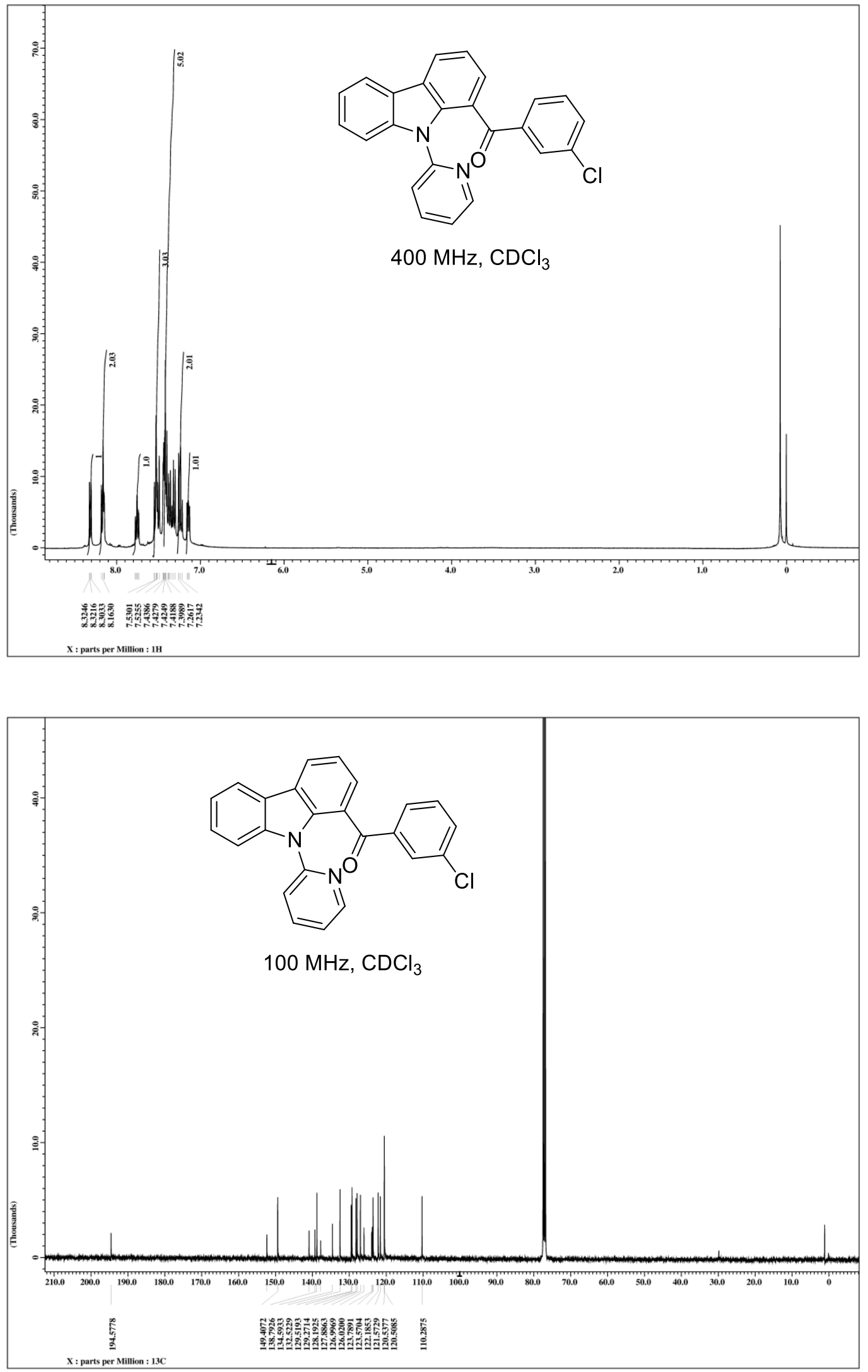
${ }^{1} \mathrm{H}$ and ${ }^{13} \mathrm{C}$ NMR of compound 3d:
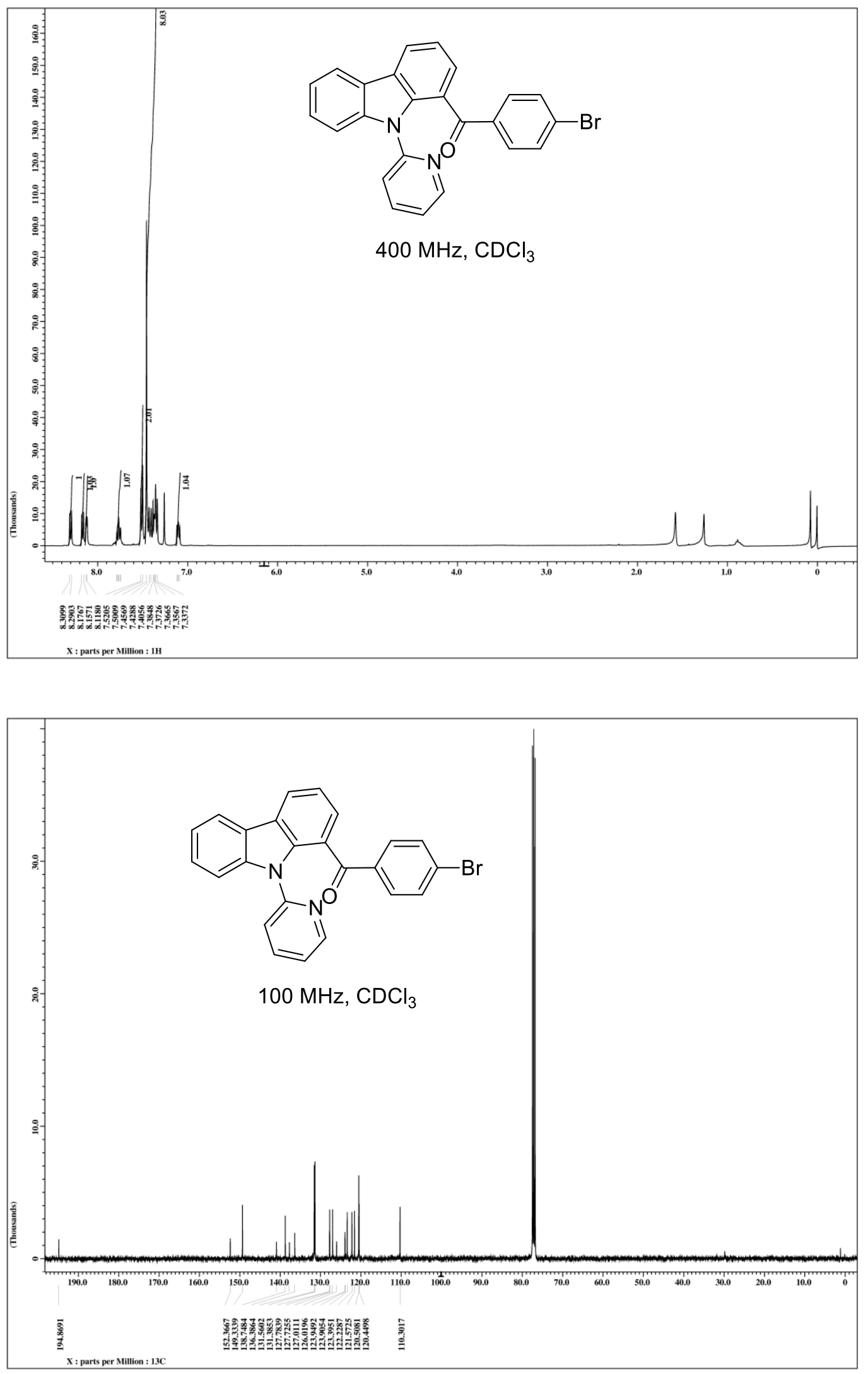
${ }^{1} \mathrm{H}$ and ${ }^{13} \mathrm{C}$ NMR of compound $\mathbf{3 e}$ :
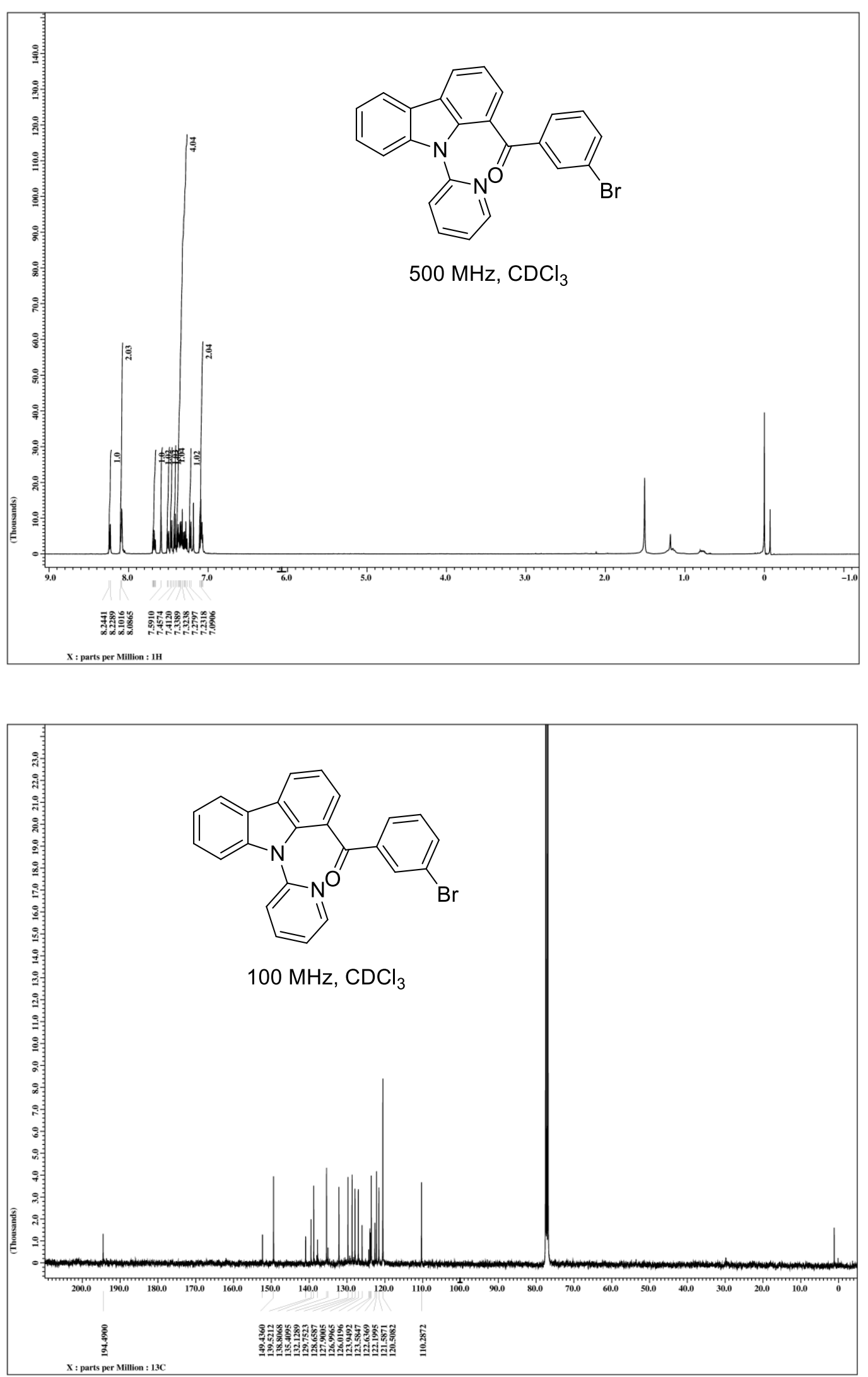
${ }^{1} \mathrm{H}$ and ${ }^{13} \mathrm{C}$ NMR of compound $\mathbf{3 f}$ :
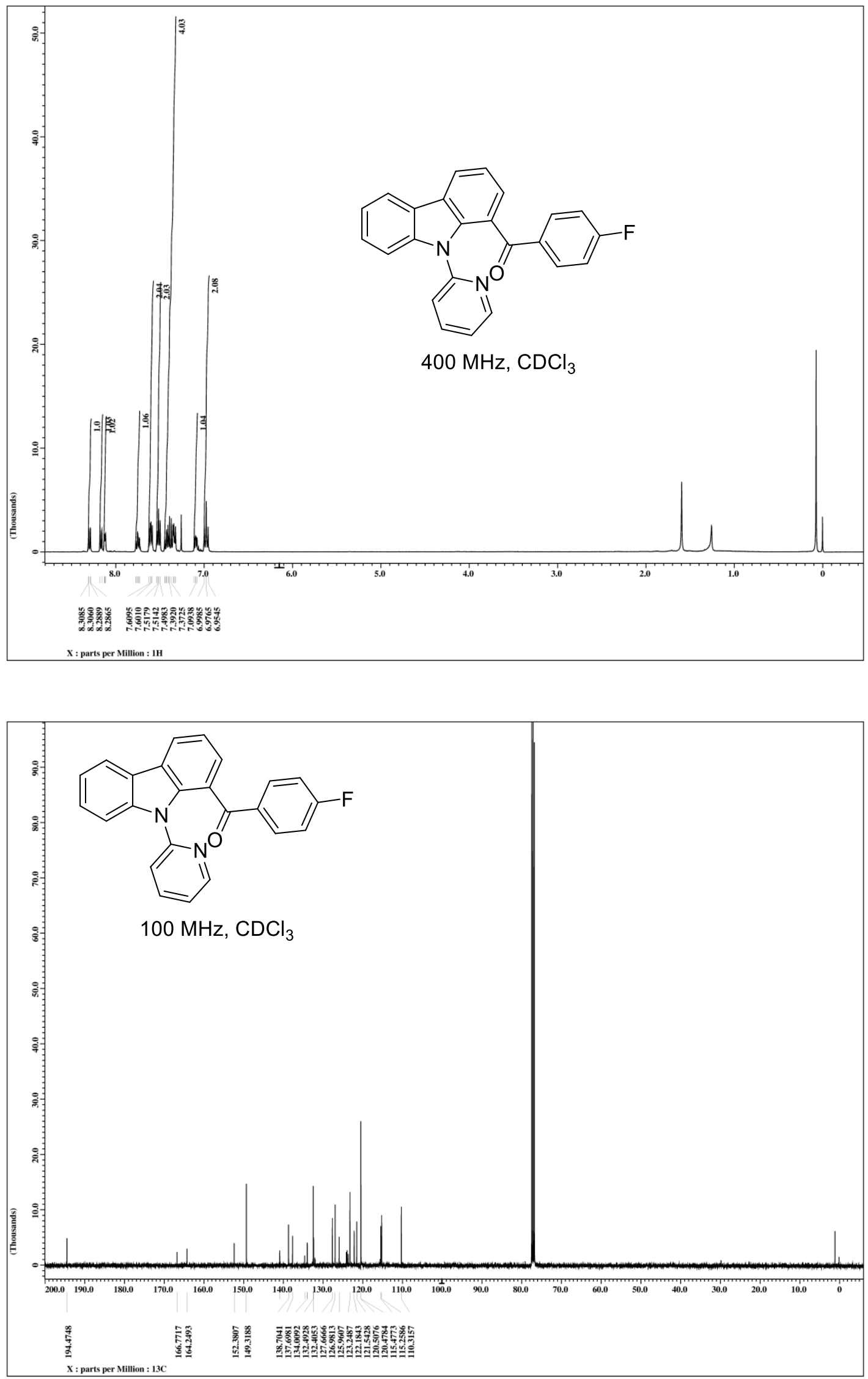
${ }^{1} \mathrm{H}$ and ${ }^{13} \mathrm{C}$ NMR of compound $\mathbf{3 g}$ :
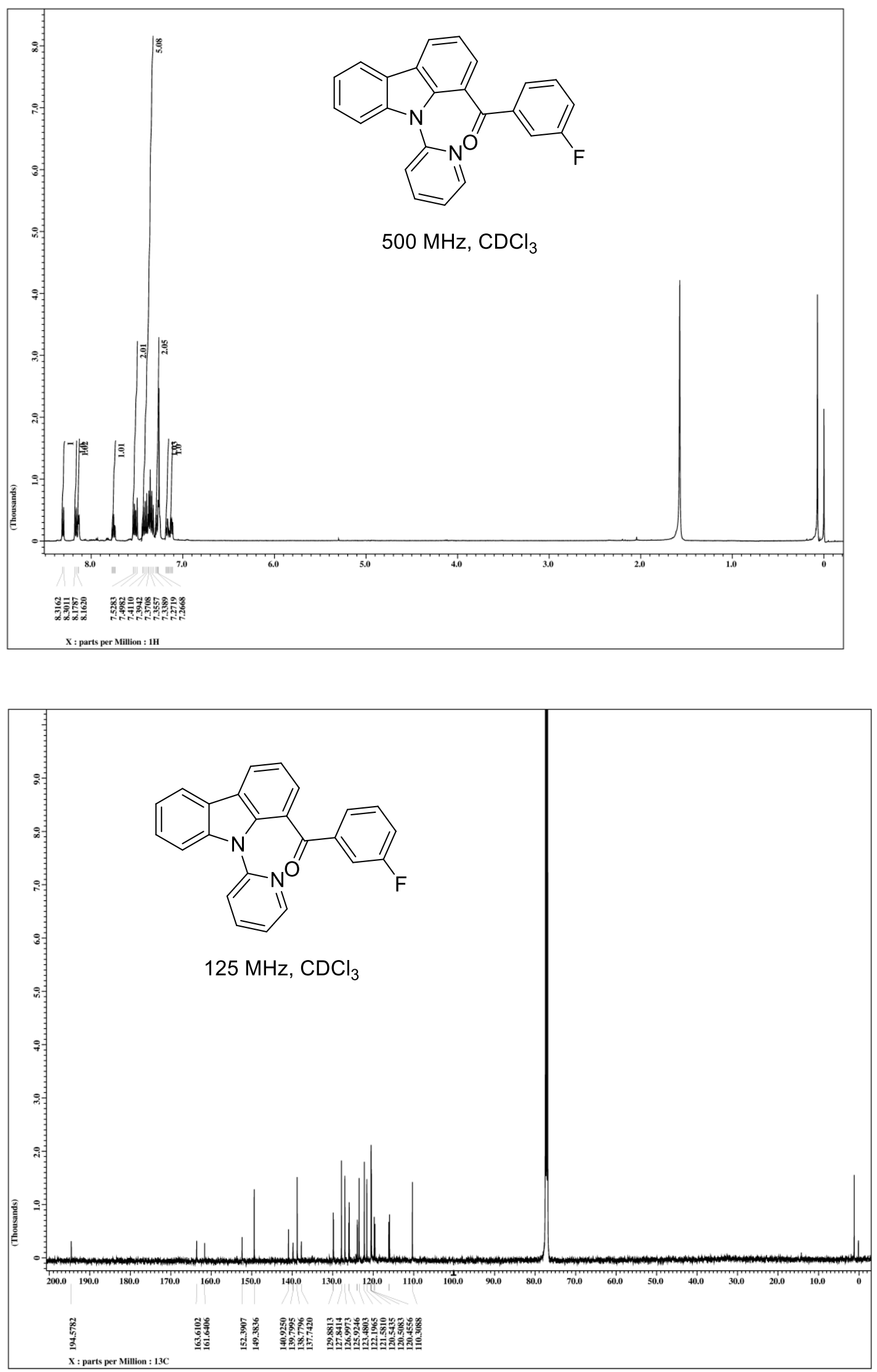
${ }^{1} \mathrm{H}$ and ${ }^{13} \mathrm{C}$ NMR of compound $\mathbf{3 h}$ :
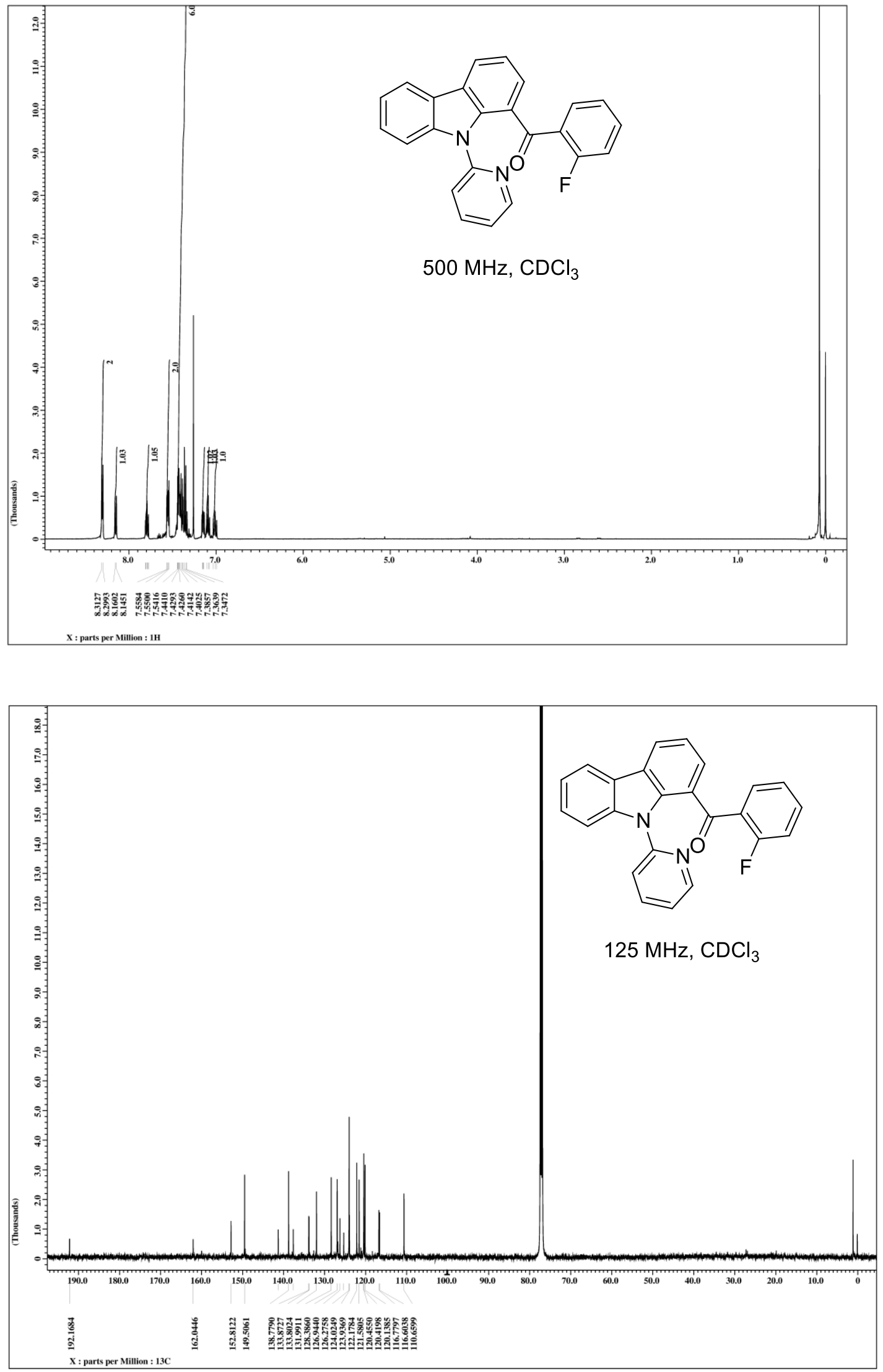
${ }^{1} \mathrm{H}$ and ${ }^{13} \mathrm{C}$ NMR of compound $\mathbf{3 i}$ :
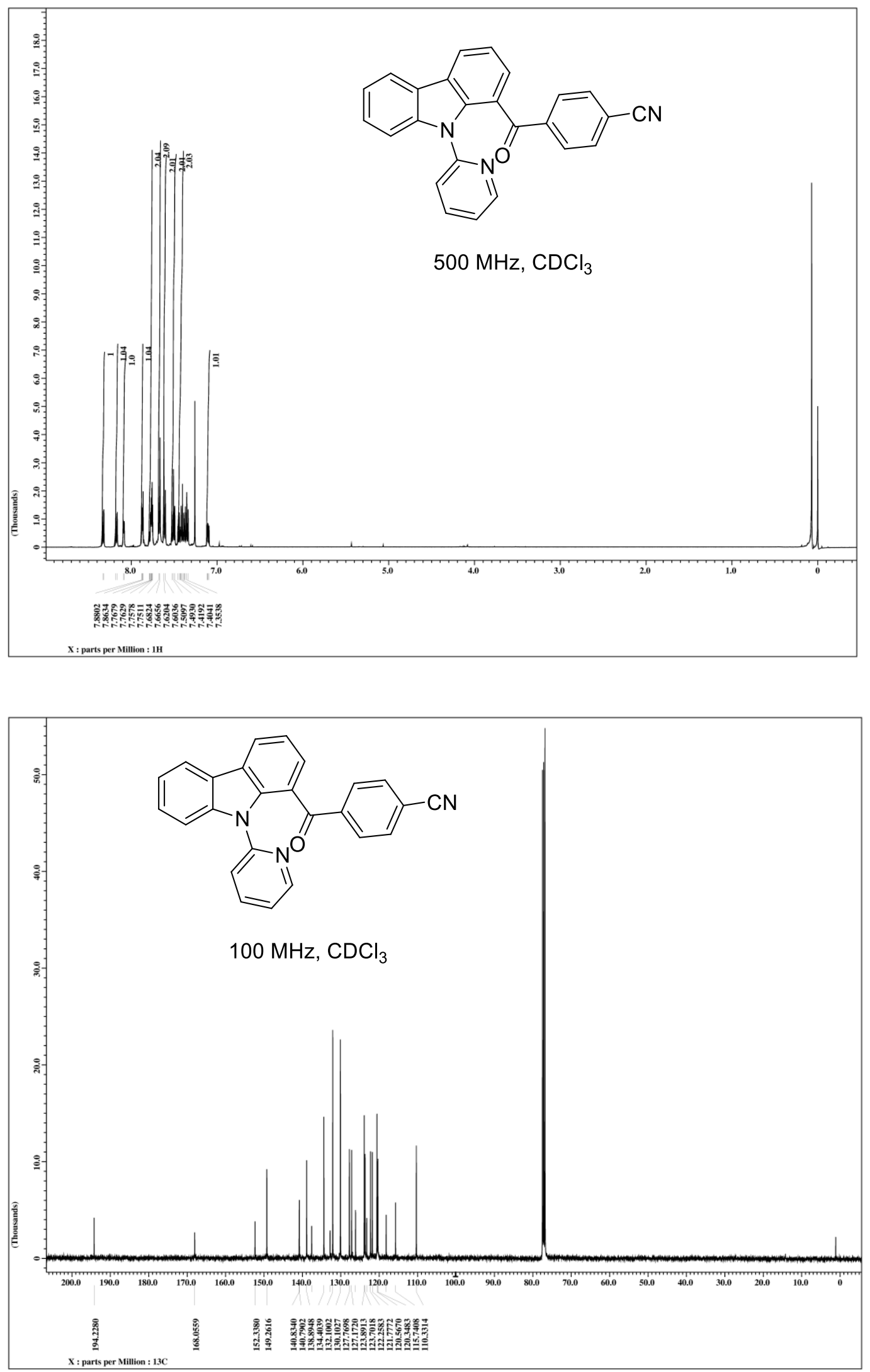
${ }^{1} \mathrm{H}$ and ${ }^{13} \mathrm{C}$ NMR of compound $\mathbf{3 j}$ :
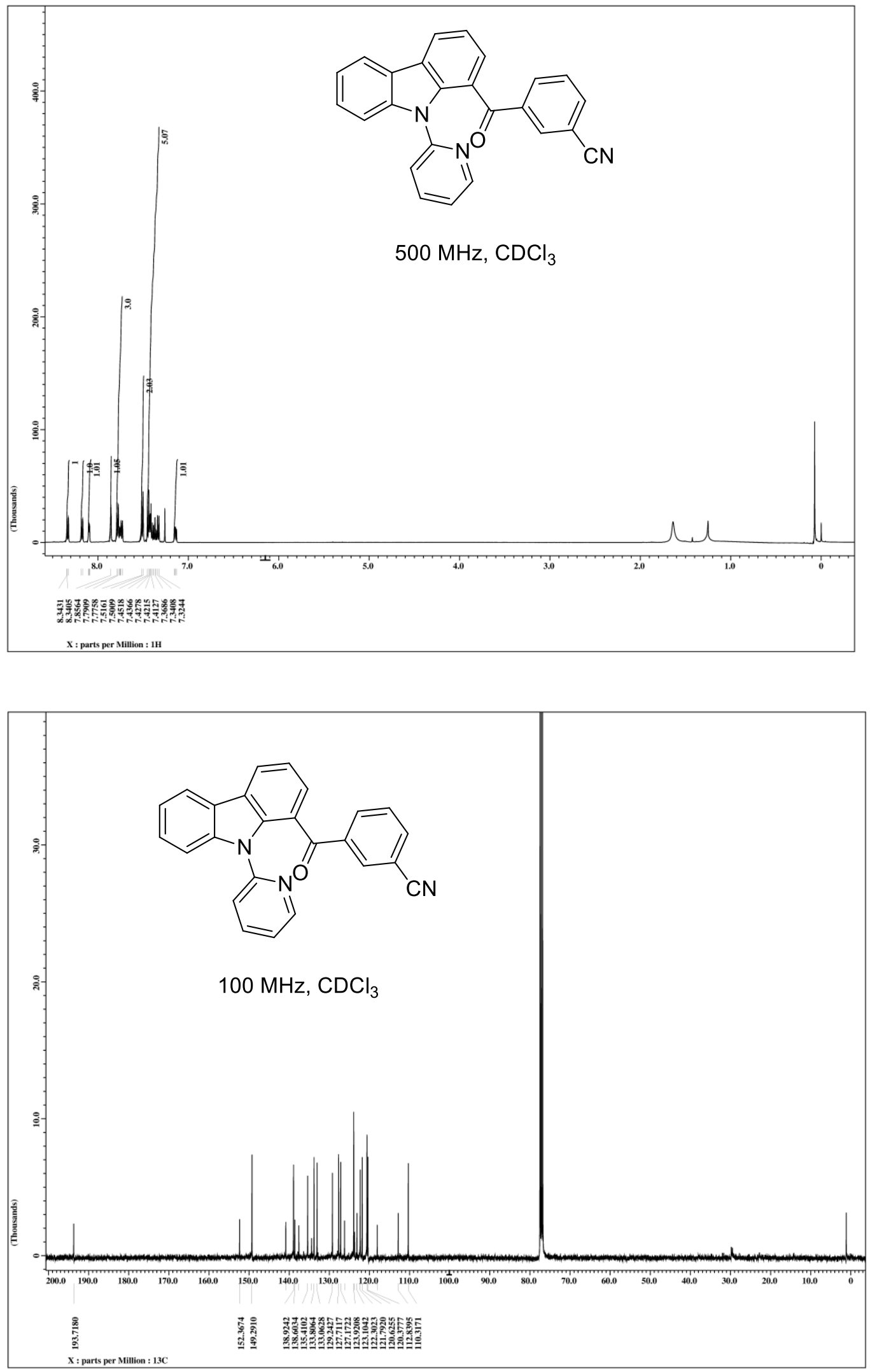
${ }^{1} \mathrm{H}$ and ${ }^{13} \mathrm{C}$ NMR of compound 3k:
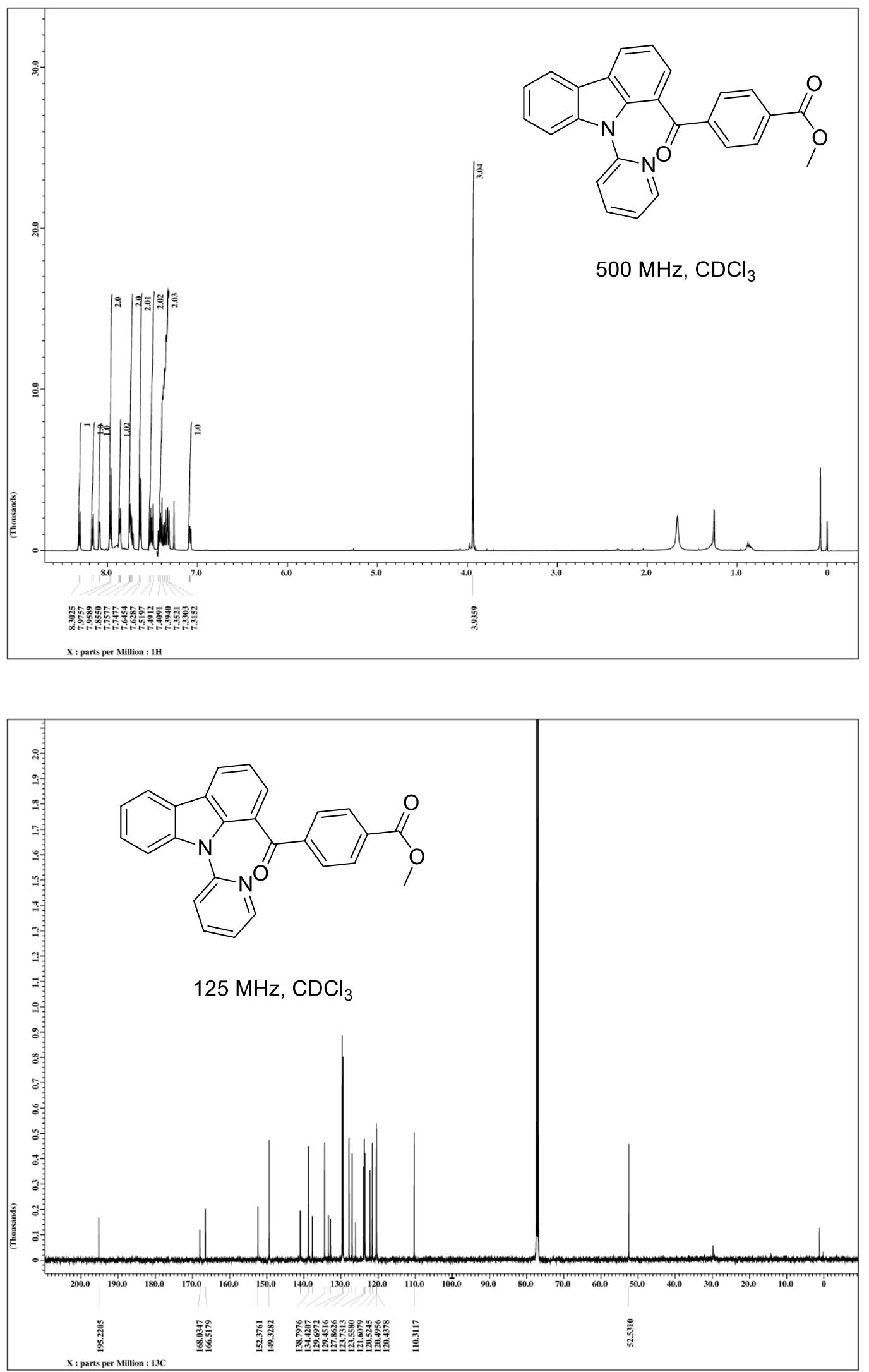
${ }^{1} \mathrm{H}$ and ${ }^{13} \mathrm{C}$ NMR of compound 3I:
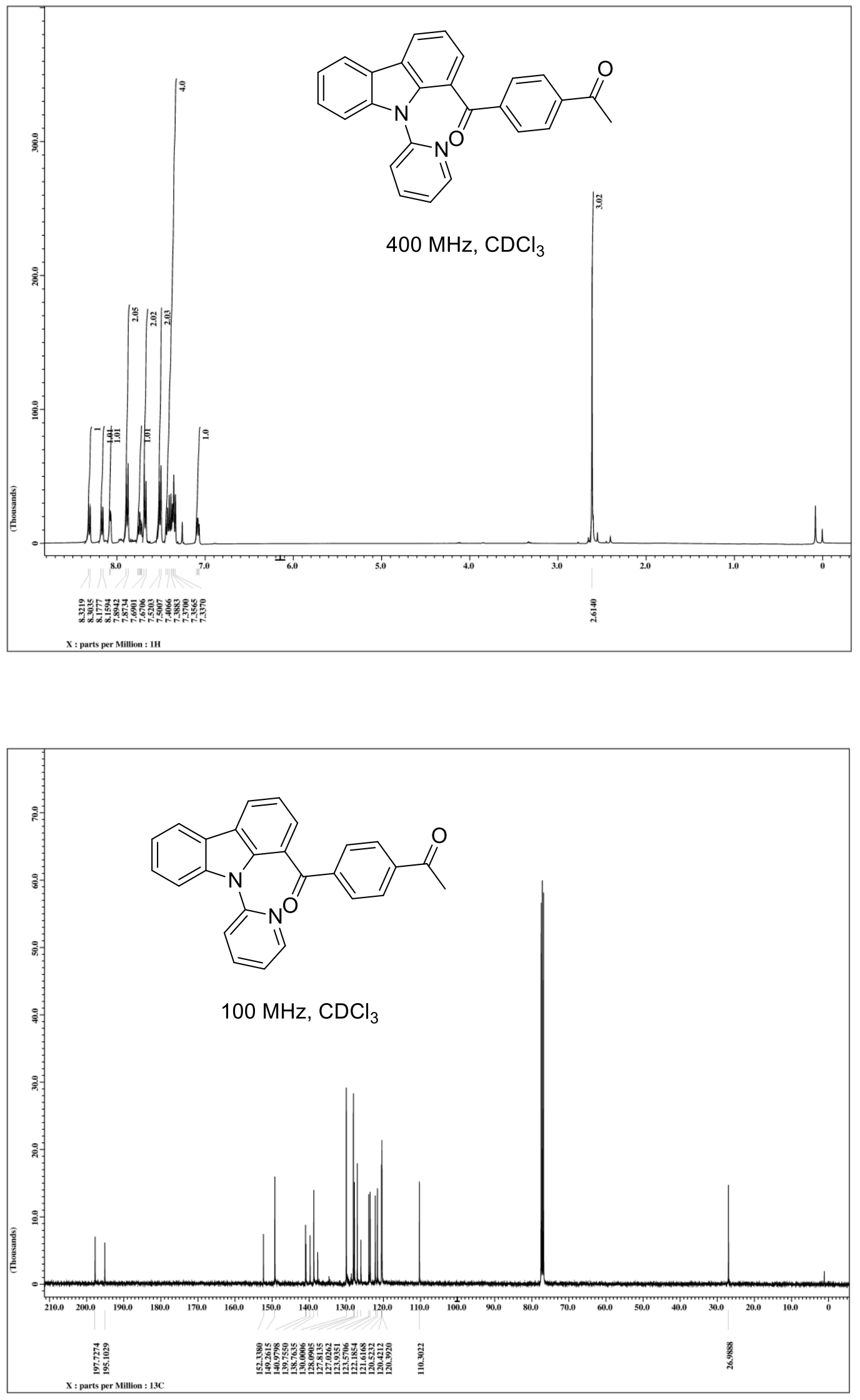
${ }^{1} \mathrm{H}$ and ${ }^{13} \mathrm{C}$ NMR of compound $\mathbf{3 m}$ :
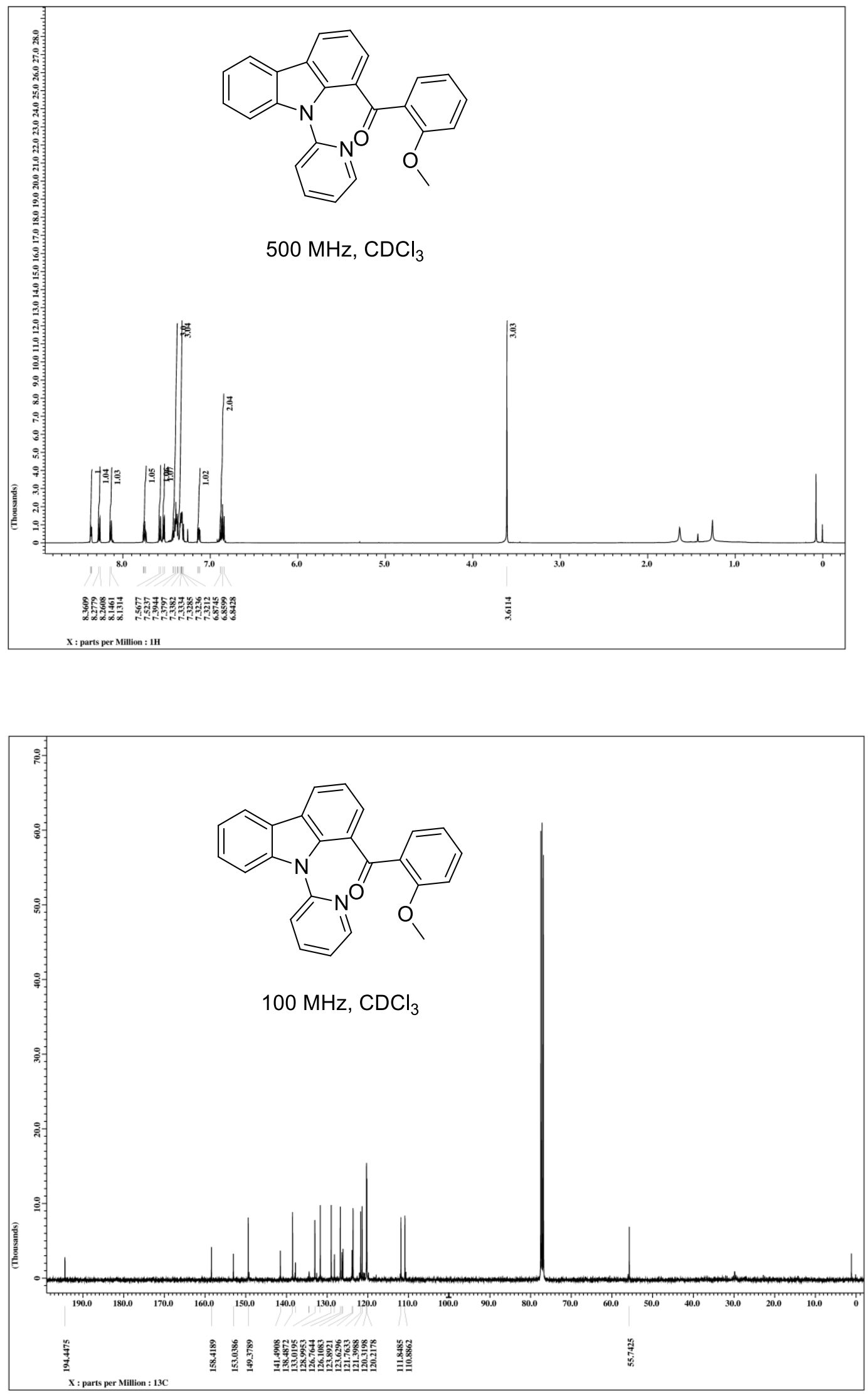
${ }^{1} \mathrm{H}$ and ${ }^{13} \mathrm{C}$ NMR of compound $\mathbf{3 n}$ :
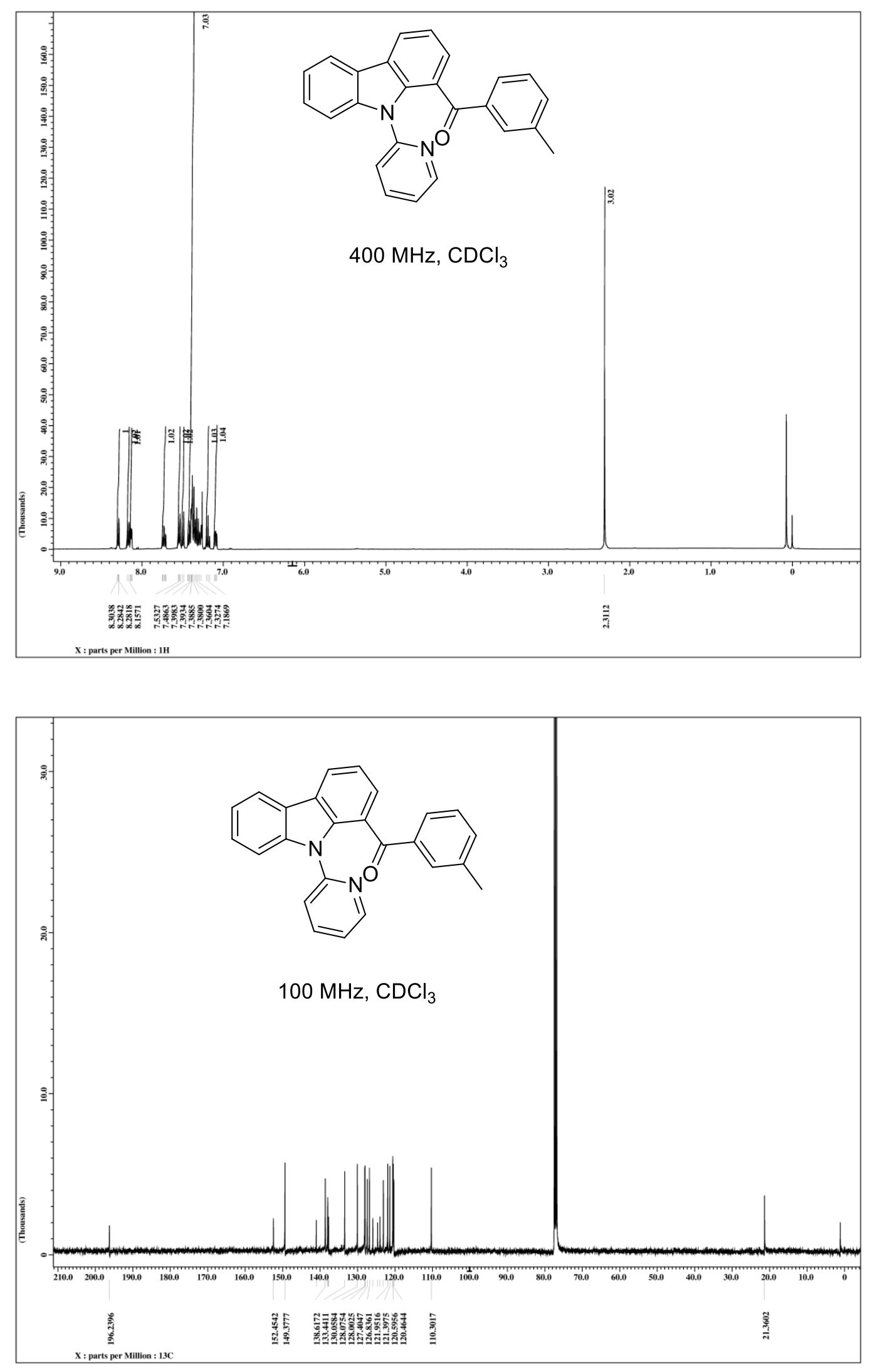

S26 
${ }^{1} \mathrm{H}$ and ${ }^{13} \mathrm{C}$ NMR of compound 3o:
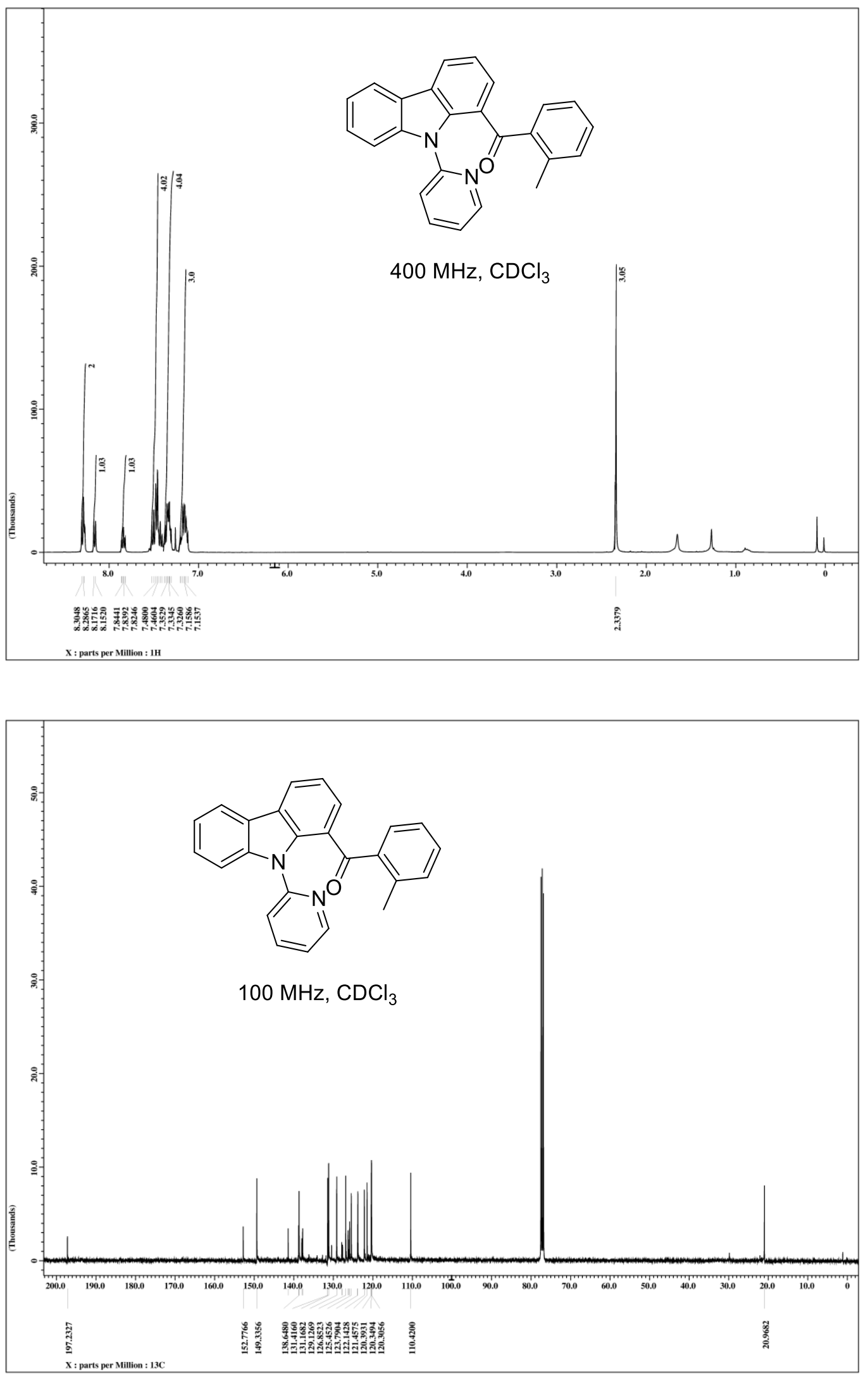
${ }^{1} \mathrm{H}$ and ${ }^{13} \mathrm{C}$ NMR of compound $\mathbf{3 p}$ :
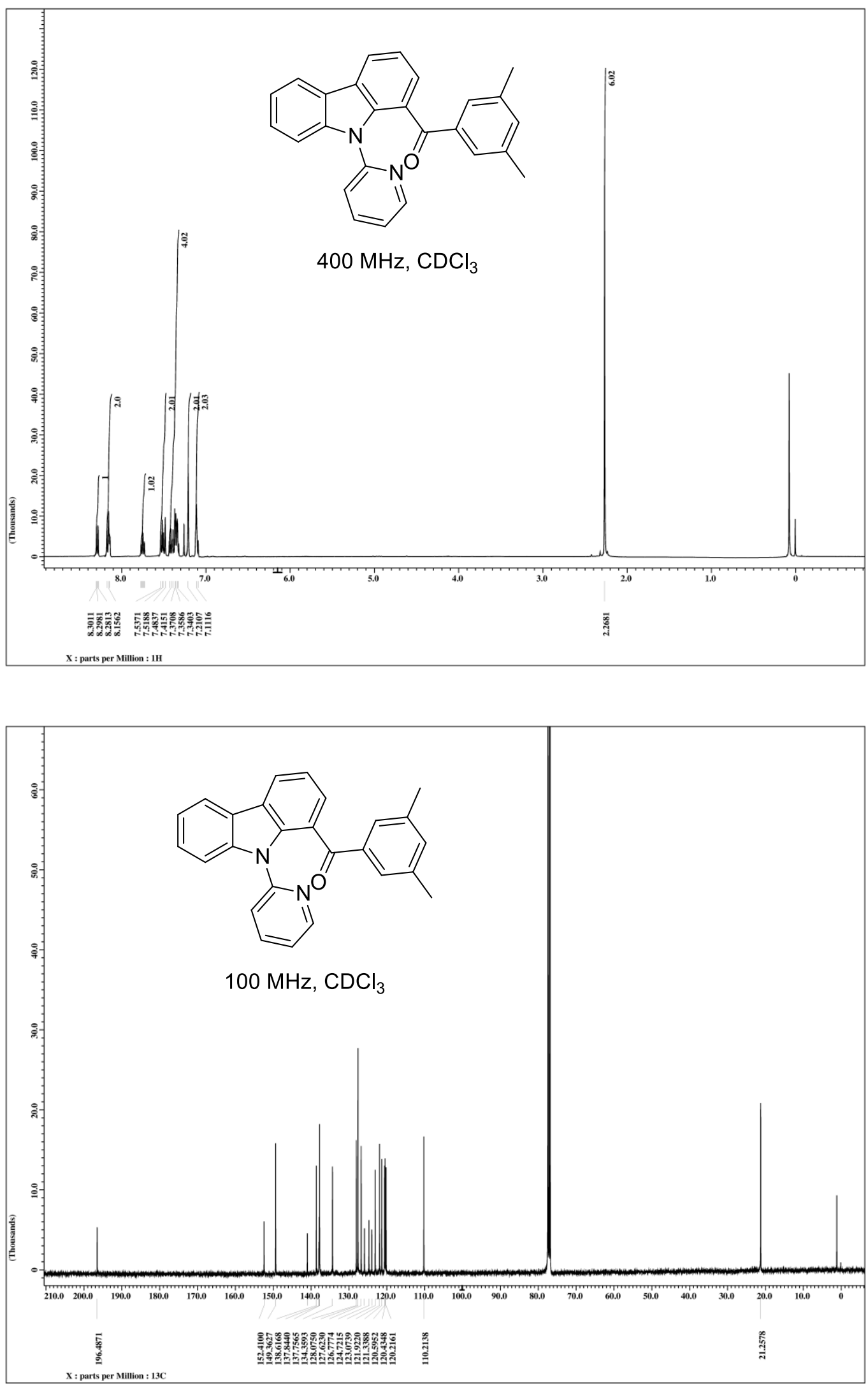
${ }^{1} \mathrm{H}$ and ${ }^{13} \mathrm{C}$ NMR of compound $\mathbf{1 0 b}$ :
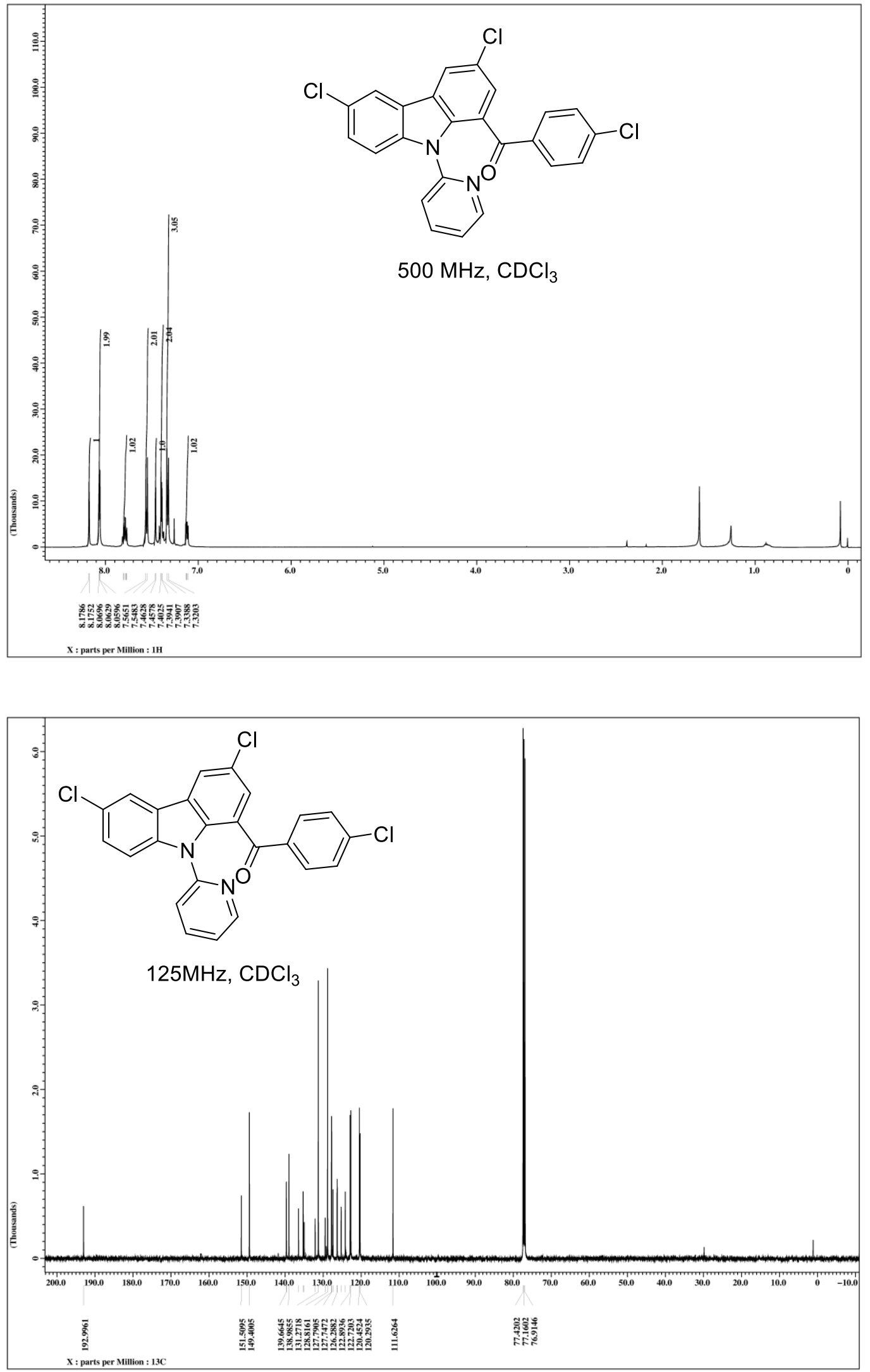
${ }^{1} \mathrm{H}$ and ${ }^{13} \mathrm{C}$ NMR of compound 11q:
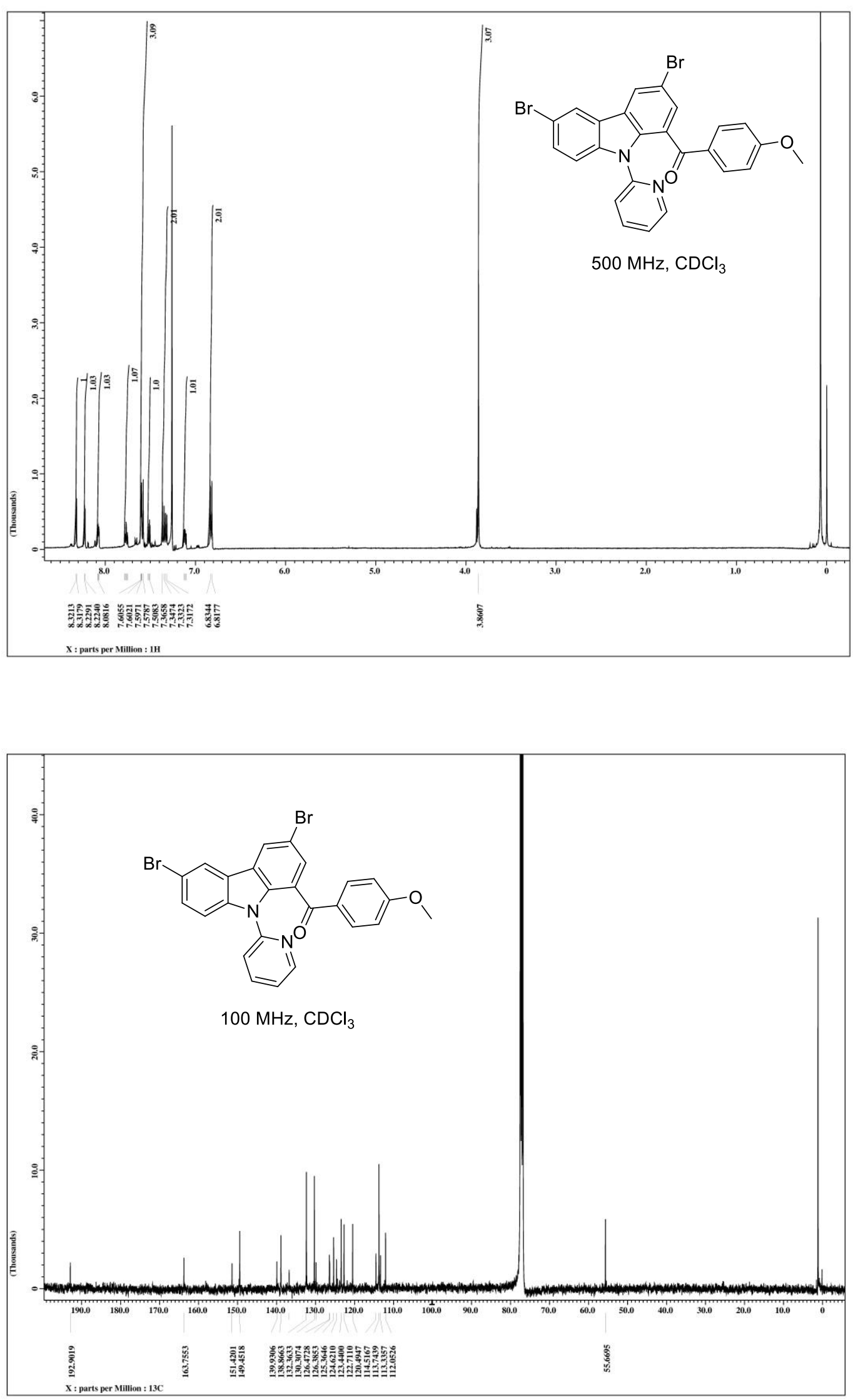
${ }^{1} \mathrm{H}$ and ${ }^{13} \mathrm{C}$ NMR of compound 11k:
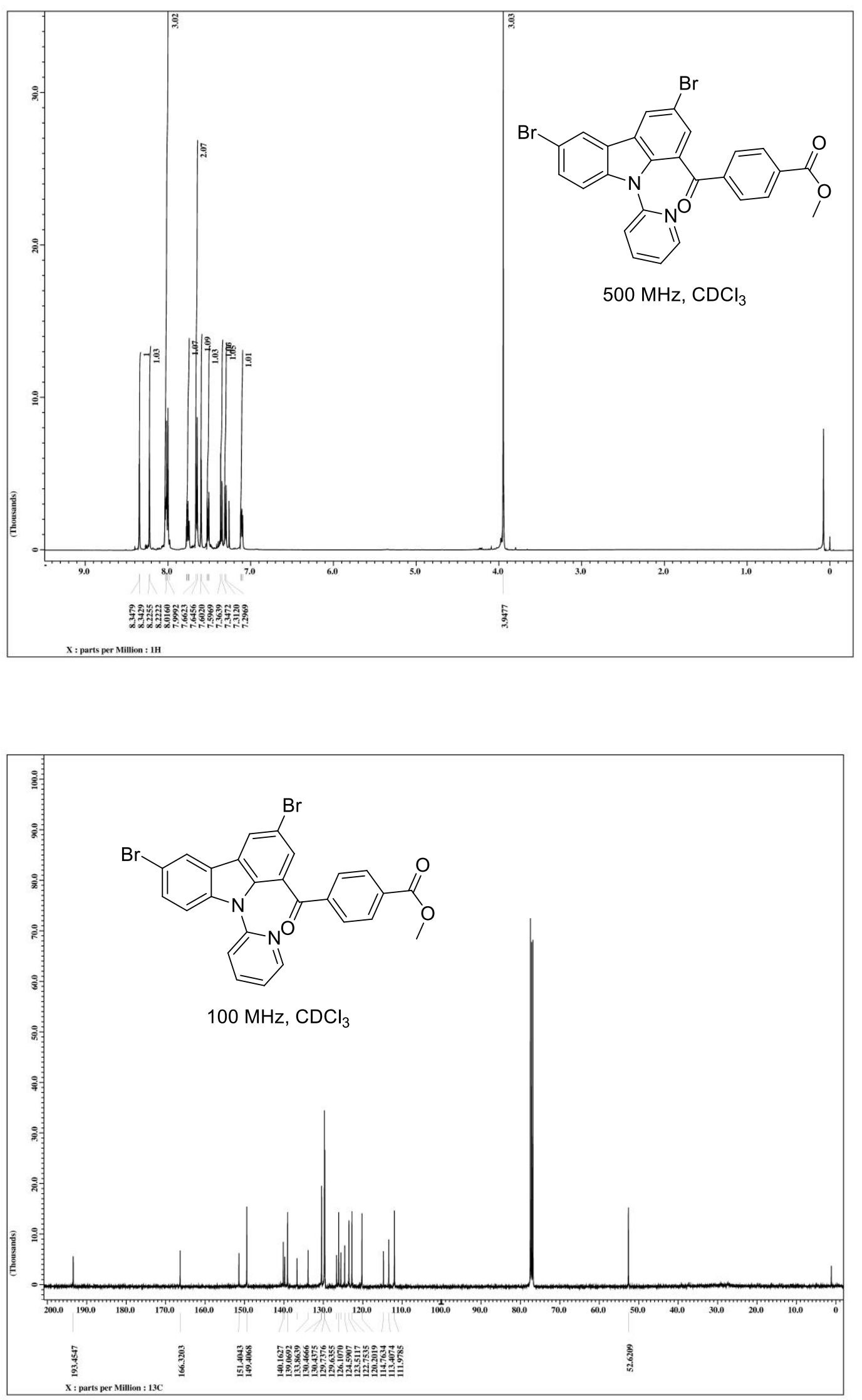
${ }^{1} \mathrm{H}$ and ${ }^{13} \mathrm{C}$ NMR of compound 12q:
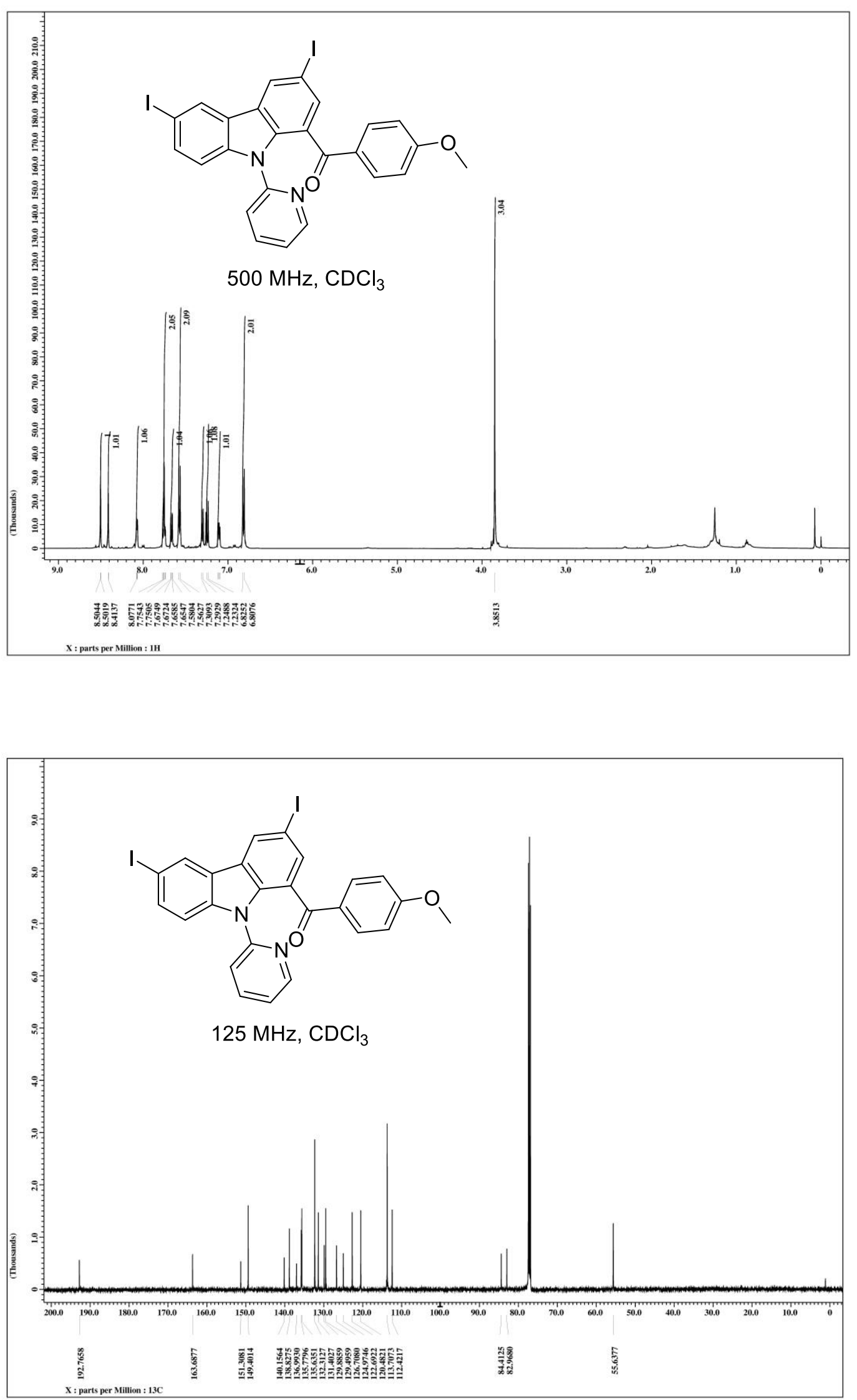
${ }^{1} \mathrm{H}$ and ${ }^{13} \mathrm{C}$ NMR of compound 12k:
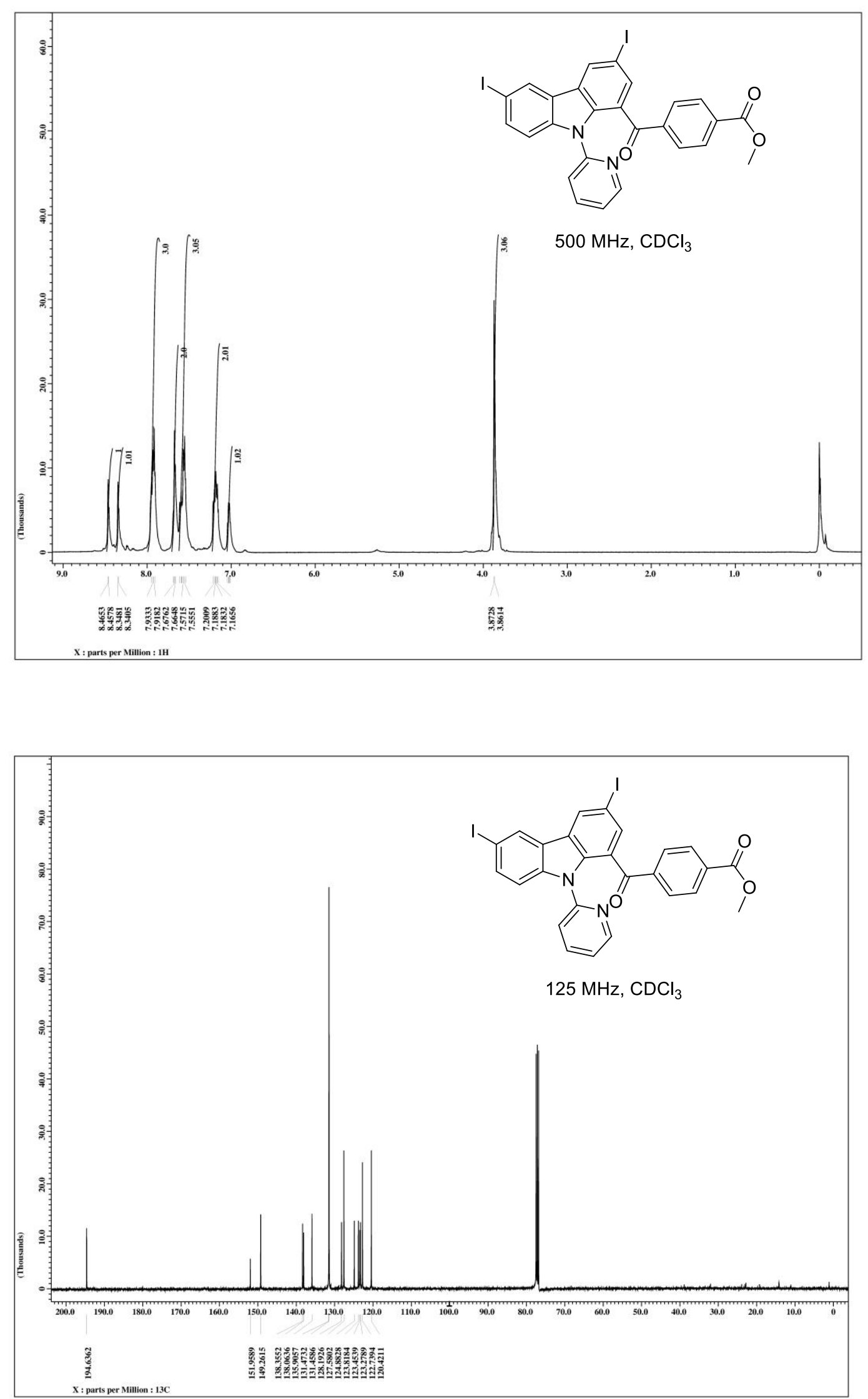
${ }^{1} \mathrm{H}$ and ${ }^{13} \mathrm{C}$ NMR of compound 13a:
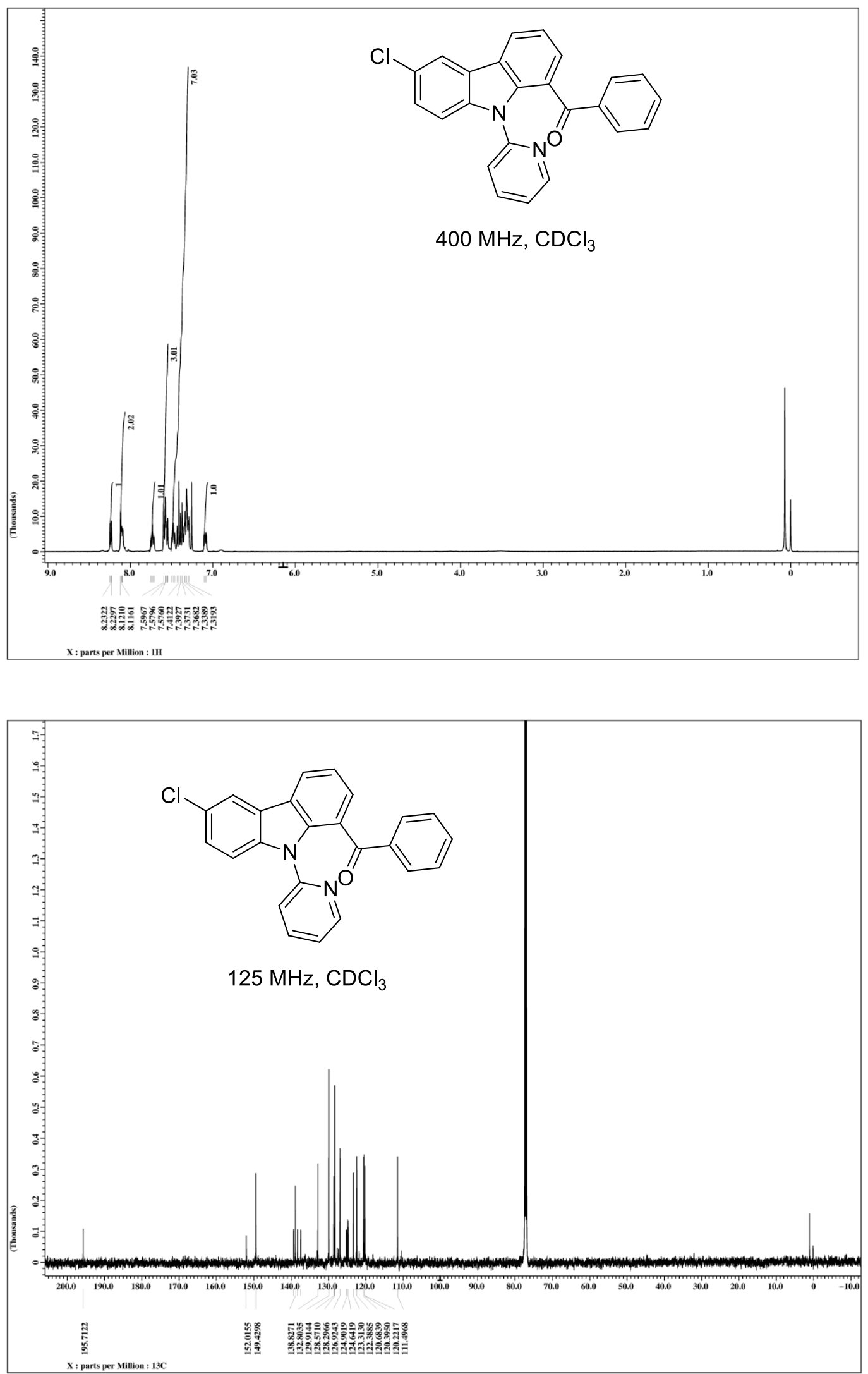
${ }^{1} \mathrm{H}$ and ${ }^{13} \mathrm{C}$ NMR of compound $\mathbf{1 4 b}$ :
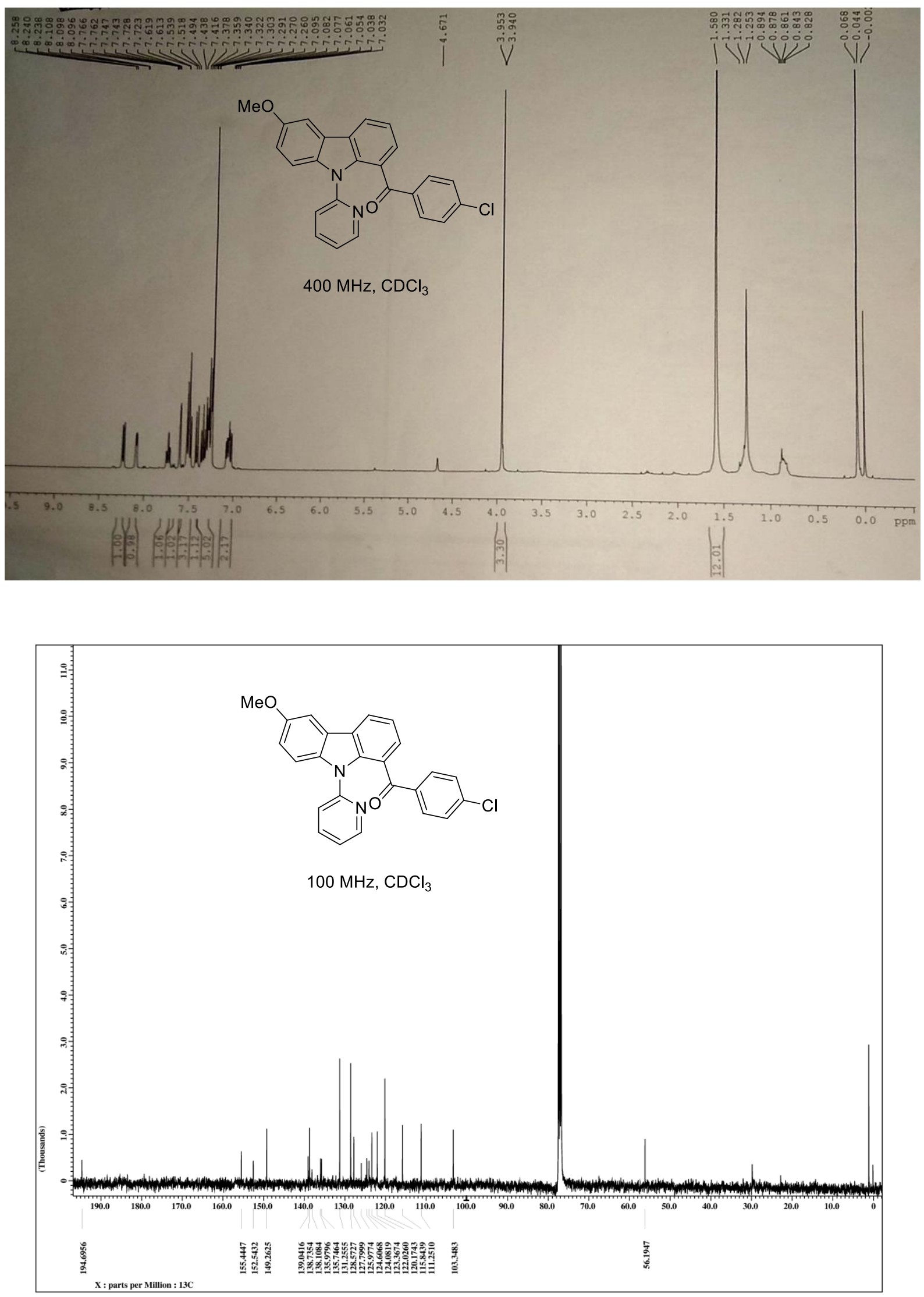
${ }^{1} \mathrm{H}$ and ${ }^{13} \mathrm{C}$ NMR of compound $3 \mathbf{r}$ :
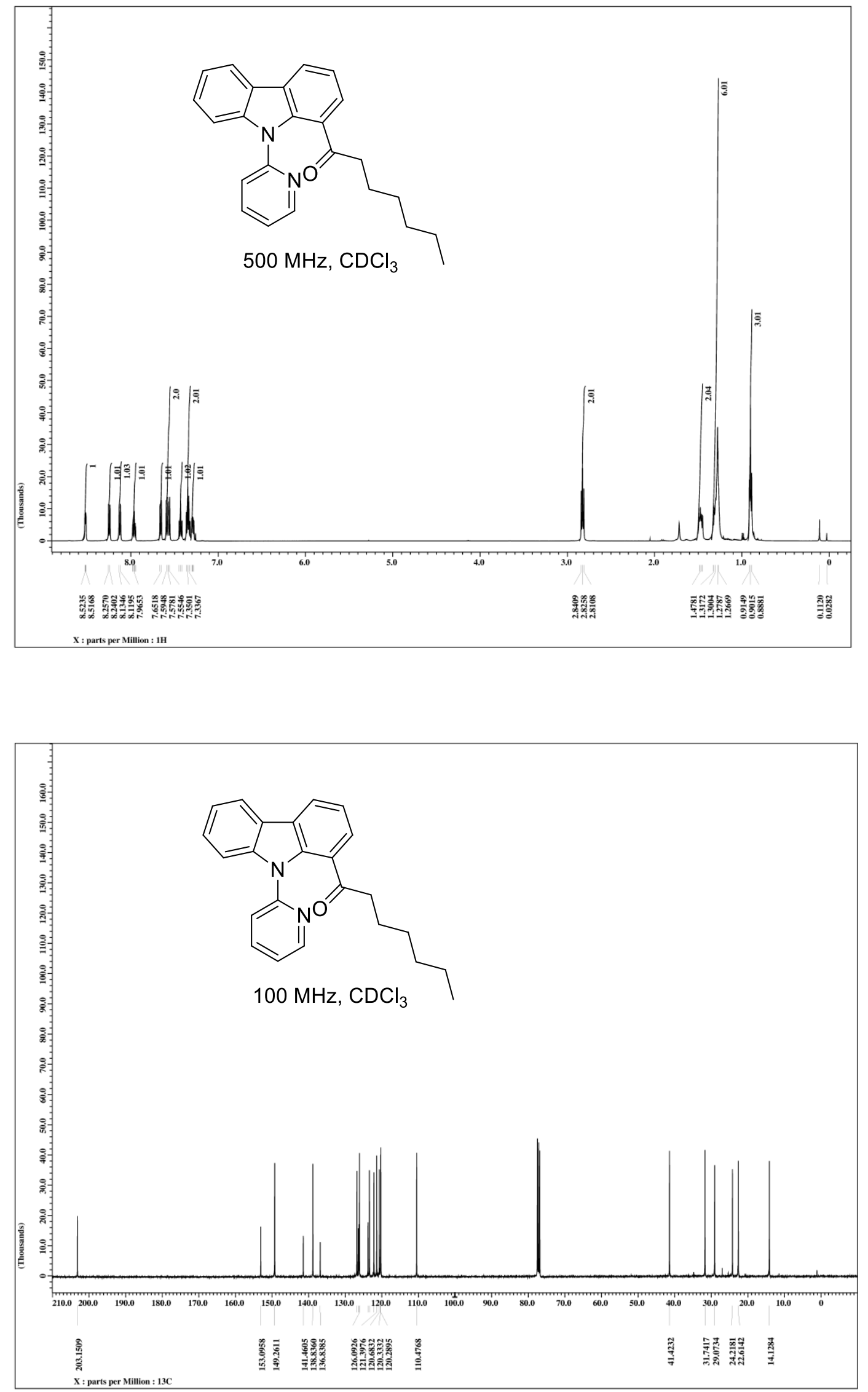
${ }^{1} \mathrm{H}$ and ${ }^{13} \mathrm{C}$ NMR of compound $\mathbf{1 7 e}$ :
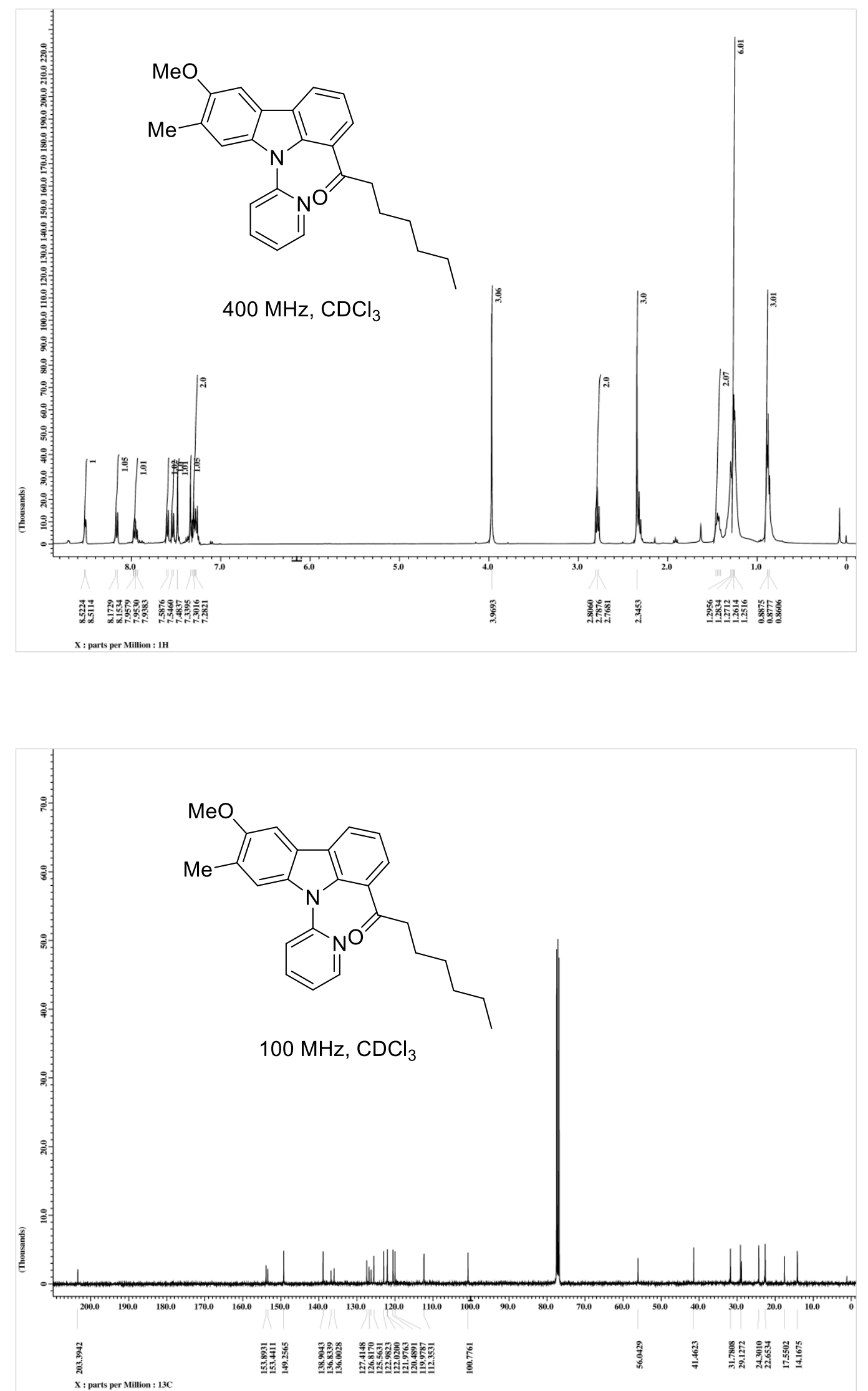